\title{
Effects of copper and butyltin compounds on the growth, photosynthetic activity and toxin production of two HAB dinoflagellates : the planktonic Alexandrium catenella and the benthic Ostreopsis cf. ovata
}

\author{
Couet Douglas ${ }^{1,2}$, Pringault Olivier ${ }^{1}$, Bancon-Montigny Chrystelle ${ }^{3}$, Briant Nicolas ${ }^{4}$, \\ Elbaz Poulichet Françoise ${ }^{3}$, Delpoux Sophie ${ }^{3}$, Yahia Ons Kéfi-Daly ${ }^{2}$, Hela Bengharbia ${ }^{2}$, \\ Charaf M'rabet ${ }^{2}$, Hervé Fabienne ${ }^{4}$, Rovillon Georges-Augustin ${ }^{4}$, Amzil Zouher ${ }^{4}$, Laabir Mohamed ${ }^{1, *}$ \\ ${ }^{1}$ Center for Marine Biodiversity, Exploitation and Conservation (MARBEC): IRD, IFREMER, CNRS, \\ Montpellier University, Montpellier, France \\ ${ }^{2}$ Research Group on Oceanography and Plankton Ecology, Tunisian National Institute of Agronomy \\ (INAT), IRESA-Carthage University, 43 Avenue Charles Nicolle, Tunis 1082, Tunisia \\ ${ }^{3}$ Hydrosciences Montpellier, CNRS, IRD, Université de Montpellier, Montpellier, France \\ ${ }^{4}$ IFREMER- Phycotoxins Laboratory, BP 21105, Nantes F-44311, France \\ *Corresponding author : Mohamed Laabir, email address : $\underline{\text { mohamed.laabir@umontpellier.fr }}$
}

\begin{abstract}
:
Controlled laboratory experiments were conducted to test the effects of copper $\left(\mathrm{Cu}^{2+}\right)$ and butyltins (BuT) on the growth, photosynthetic activity and toxin content of two HABs (Harmful Algal Blooms) dinoflagellates, the planktonic Alexandrium catenella and the benthic Ostreopsis cf. ovata. Microalgae were exposed to increasing concentrations of $\mathrm{Cu}^{2+}\left(10^{-4}\right.$ to $\left.31 \mathrm{nM}\right)$ or BuT $(0.084$ to $84 \mathrm{nM})$ for seven days. When considering the growth, $\mathrm{EC}_{50}$ values were $0.16( \pm 0.09) \mathrm{nM}$ and $0.03( \pm 0.02) \mathrm{nM}$ of $\mathrm{Cu}^{2+}$ for $A$. catenella and $O$. cf. ovata, respectively. Regarding BuT, $\mathrm{EC}_{50}$ was $14.2( \pm 6) \mathrm{nM}$ for $O$. cf. ovata, while $A$. catenella growth inhibition appeared at BuT concentrations $\geq 27 \mathrm{nM}$. Photosynthetic activity of the studied dinoflagellates decreased with increasing $\mathrm{Cu}$ and BuT concentrations. For $\mathrm{O}$. cf. ovata, the response of this physiological parameter to contamination was less sensitive than the biomass. $\mathrm{Cu}$ exposure induced the formation of temporary cysts in both organisms that could resist adverse conditions. The ovatoxin- $a$ and $-b$ concentrations in $O$. cf. ovata cells increased significantly in the presence of $\mathrm{Cu}$. Altogether, the results suggest a better tolerance of the planktonic $A$. catenella to $\mathrm{Cu}$ and BuT. This could result in a differentiated selection pressure exerted by these metals on phytoplankton species in highly polluted waters. The over-production of toxins in response to Cu stress could pose supplementary health and socio-economic threats in the contaminated marine ecosystems where HABs develop.
\end{abstract}




\section{Highlights}

- Growth rate and photosynthetic activity of the studied dinoflagellates decreased with increasing $\mathrm{Cu}$ and BuT concentrations. Alexandrium catenella was more tolerant to $\mathrm{Cu}$ and butyltins compared to Ostreopsis cf. ovata. $-\mathrm{Cu}$ induced the formation of temporary cysts for both species. $>\mathrm{Cu}$ induced toxin production in Ostreopsis cf. ovata.

Keywords : Alexandrium catenella, Ostreopsis cf. ovata, $\mathrm{Cu}$, butyltin, photosynthesis, toxins 


\section{Introduction}

Pollution of the marine environment is one of the biggest challenges facing humanity, as it can impact issues related to health, economic and environmental (Schwarzenbach et al., 2006). Metal input in marine ecosystems particularly raises concerns, since it has become one of the major pollution types ever recorded (Naser, 2013). Among this kind of contaminants, $\mathrm{Cu}$ and organotins have been widely used for decades in industrial activities, such as petroleum refining and the manufacture of antifouling chemical products (Alzieu et al., 1991; Wake, 2005). Tributyltin (TBT), a butyltin (BuT) compound, was designed in the 1950's as the most effective anti-fouling system available in the market for decades (Omae, 2006). However, TBT has been shown to induce imposex (female develops male sex organs such as a penis and a vas deferens) in the gastropod Nucella lapillus but also serious anomalies in calcification mechanisms in the oyster Crassostrea gigas which could lead to population decline (Bettin et al., 1996; Gibbs and Bryan, 1986, Alzieu et al. 1986). Due to its global harmful effects on marine biota at very low concentrations (a few ng $\mathrm{L}^{-1}$ ) (Smith, 1996; Solé et al., 1998), TBT was banned from antifouling paints for boats by the International Maritime Organisation in 2008. However, despite this ban, TBT and butyltins in general are still use inland (as biocides in agriculture, catalysts, and heat stabilizers for polyvinylchloride, PVC) and continue to be released in marine coastal waters through urban and industrial sewage sludge (Díez et al., 2002; Sabah et al., 2016). TBT persists in high concentrations

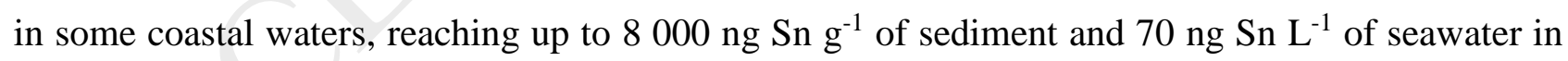
some ecosystems (Abidli et al., 2015; Briant et al., 2016; Hartwell et al., 2016). TBT replacement by $\mathrm{Cu}$ in antifouling paint coincided with an increase in the use of $\mathrm{Cu}$ in industrial activities or as a biocide, and this has resulted in $\mathrm{Cu}$ accumulation in marine sediments and waters (Cossa et al., 2017; Zohra and Habib, 2016). The United States Environmental Protection Agency (US EPA) considered $\mathrm{Cu}$ as one of the greatest environmental concerns in vessel discharges (Tornero and Hanke, 2016), indicating multiple potential negative impacts of $\mathrm{Cu}$ on marine organisms. Hence, 
phytoplankton species are able to bio-accumulate a wide range of pollutants including $\mathrm{Cu}$ and butyltin and can transfer them to higher trophic levels, leading to dramatic effects on many organisms (Flouty and Estephane, 2012; Fortibuoni et al., 2013).

During the last few decades, anthropization was argued to be a causative factor of harmful algal blooms (HABs) (Berdalet et al., 2016; Davidson et al., 2014). HABs have become a serious problem in many coastal marine ecosystems, since their distribution, frequency and intensity is continuously increasing (Anderson et al., 2012; Sellner et al., 2003). Among HAB dinoflagellate species, the planktonic Alexandrium catenella and the benthic Ostreopsis cf. ovata are characterized by high toxicity. A. catenella and $O$. cf. ovata are producers of paralytic shellfish toxins (PSTs) and ovatoxins, respectively (Amzil et al., 2012; Hallegraeff, 1993). They intoxicate marine organisms and humans through the consumption of marine mollusks or the breathing of marine aerosols and thus threaten public health and socio-economic activities (Accoroni et al., 2011; Parsons et al., 2012). However, the sensitivity of these harmful organisms to metal pollution was scarcely studied, although the $\mathrm{Cu}$ effects on numerous phytoplankton species have been widely investigated. $\mathrm{Cu}$ is essential for living organisms as it is involved in many metabolic processes, such as photosynthesis and mitochondrial respiration (Hänsch and Mendel, 2009). It also forms complexes with cellular proteins, such as plastocyanin (Jansson et al., 2003) and cytochrome c oxidase (Peiffer et al., 1990). However, signs of cellular stress and growth inhibition appear at high $\mathrm{Cu}$ concentrations, with the $\mathrm{EC}_{50}$ (concentration corresponding to $50 \%$ of the activity relative to control) values for phytoplankton being at the $\mu \mathrm{M}$ level (Perales-Vela et al., 2007; Yan and Pan, 2002). Cu impacts photosynthesis in various ways, affecting both pigment concentration and photosystem II (PSII) efficiency. In PSII, $\mathrm{Cu}$ inhibits the electron transport at P680 and leads to the closing of reaction centers (Cid et al., 1995; Schroders et al., 1994). It can also alter the rate of oxidoreduction, leading to an impairment of PSII electron transport (Jegerschold et al., 1995; Yruela et al., 1992). The toxicity of dissolved metals to phytoplankton is not related to their total concentration but to their free ion activity (Santore et al., 2001; Waite and Morel, 1983). This is particularly important for $\mathrm{Cu}$, 
which has a strong affinity for organic ligands, such as ethylene diamine tetra-acetic acid (EDTA) commonly used in culture media and which decreases $\mathrm{Cu}$ toxicity. However, despite the important number of studies concerning $\mathrm{Cu}$ effects on phytoplankton, only a few give the $\mathrm{Cu}^{2+}$ concentration, making comparison between studies or in situ values difficult to achieve. On the other hand, butyltin toxicity studies have mainly focused on invertebrates and fishes (Hanana et al., 2014; Kwok and Leung, 2005), and the lack of studies on phytoplankton has been highlighted (Petersen and Gustavson, 2000). Few studies tested the TBT effects on microalgae; for example, the chlorophyte Tetraselmis suecica density and chlorophyll biomass were impacted with an $\mathrm{EC}_{50}$ of 20 $\mu \mathrm{g} \mathrm{mL} \mathrm{L}^{-1}$ (Yong et al., 2007). The microalgae Nannochloropsis oculata was more sensitive, with an $\mathrm{EC}_{50}$ of $0.89 \mathrm{nM}$, and it showed a decrease in pigment and protein content after TBT exposure (Sidharthan et al., 2002). However, a more precise investigation of TBT effects on photosystem activity (such as maximum quantum yield of photosynthesis) are still lacking in the literature.

Despite the large number of studies of $\mathrm{Cu}$ effects on phytoplankton, and to a smaller extent of butyltin, only a few considered harmful species, particularly benthic species. It has been shown that under $\mathrm{Cu}$ exposure, Prorocentrum minimum and Alexandrium catenella, two toxic dinoflagellates, showed an inhibition of growth, maximum quantum yield of photosynthesis (Fv/Fm) and pigment concentration (Herzi et al., 2013; Lage et al., 1994; Miao et al., 2005). Photosystem gene expression was also decreased in the Cu-treated P. minimum (Guo et al., 2016), indicating gene regulation action of $\mathrm{Cu}$. Until now, the effect of $\mathrm{Cu}$ and $\mathrm{BuT}$ has not been investigated in O. cf ovata. It has been shown that some environmental factors, such as temperature, irradiance and nutrients, could affect the toxin content of some dinoflagellate species (Etheridge and Roesler, 2005; Pezzolesi et al., 2012). However, the observed effects on toxin content and profile could be contradictory depending on the coupled abiotic factor/microalgae species, showing complex and variable responses (Anderson et al., 2012; Laabir et al., 2013). Regarding the metallic stress effect on toxin production, very few studies have been performed on HAB species. Yessotoxin content increased in Protoceratium reticulatum cells treated with selenium at the pM level, but not when treated with 
iron or cobalt (Mitrovic et al., 2004). Similarly, production of domoic acid by Pseudo-nitzschia australis increased under $\mathrm{Cu}$ exposure (Maldonado et al., 2002). These studies highlighted a potential metal effect on toxin production in HAB species. To our knowledge, this has never been investigated for $\mathrm{Cu}$ and butyltin.

The main objective of this study was to investigate the effects of $\mathrm{Cu}$ and $\mathrm{BuT}$ on the growth, photosynthetic efficiency and toxin production of the harmful dinoflagellates A. catenella and $O$. cf. ovata through controlled laboratory experiments. Moreover, cupric ion concentrations $\left(\mathrm{Cu}^{2+}\right)$ were calculated to compare our results with literature data and in situ concentrations.

\section{Material and methods}

\subsection{Dinoflagellate cultures}

Non-axenic monoclonal cultures of the benthic toxic dinoflagellate Ostreopsis cf. ovata (OOBZT14) were conducted using enriched natural seawater medium (ENSW) (Harrison et al., 1980), at stable conditions of salinity 36 , temperature of $25^{\circ} \mathrm{C}$ and irradiance of $100 \mu \mathrm{mol}$ photons $\mathrm{m}^{-2} \mathrm{~s}^{-1}$ in a 12:12 light:dark cycle. The planktonic dinoflagellate Alexandrium catenella (ABZ1) was cultured under the same conditions, but at a temperature of $20^{\circ} \mathrm{C}$ and salinity 35 corresponding to its optimal growth. OOBZT14 and ABZ1 strains were isolated in the Bay and the lagoon of Bizerte (Western Mediterranean Tunisia), respectively (Ben-Gharbia et al., 2016; Fertouna-Bellakhal et al., 2015).

2.2 Spiking solutions of $\mathrm{Cu}(\mathrm{Cu})$ and TBT: preparation and determination of initial and final concentrations

$\mathrm{Cu}$ - and TBT-supplemented stock solutions were prepared with $\mathrm{CuCl}_{2}$ and $\left[\mathrm{CH}_{3}\left(\mathrm{CH}_{2}\right)_{3}\right]_{3} \mathrm{SnCl}$ salts (Merck), respectively, diluted in ENSW medium. Triplicates of $250 \mathrm{~mL}$ sterile plastic flasks (final culture volume of $200 \mathrm{~mL}$ ) were obtained with nominal concentrations of 15.7, 157, 504, 1575, 5039, 15748 and $50394 \mathrm{nM}$ of $\mathrm{Cu}$ and $0.085,0.27,0.85,2.7,8.5,27$ and $85 \mathrm{nM}$ of TBT. 


\subsubsection{Copper measurements}

Despite the presence of EDTA (ethylene diamine tetra-acetic acid, a complexing agent facilitating the assimilation of micro-nutrients by the microalgae) in the culture medium, which forms complexes with $\mathrm{Cu}$ in solution, $\mathrm{Cu}$ could adsorb on flask walls or on cell surfaces or be taken up by the phytoplankton cells. Therefore, in order to better characterize the $\mathrm{Cu}$ exposure of $\mathrm{A}$. catenella and $O$. cf. ovata, the dissolved concentration of $\mathrm{Cu}$ was measured in the flasks at the beginning (day 0) and at the end (day 7) of the incubations. For this, aliquots of the culture were filtered through $0.22 \mu \mathrm{m}$ acetate cellulose filters and acidified with nitric acid Merck Suprapur. Analyses were carried out using ICP-MS-Q, iCAP-Q (Thermo Scientific) equipped with a high matrix interface. More details on the analytical procedure can be found in Pringault et al. (2016).

The bioavailable $\mathrm{Cu}^{2+}$ concentration in the ENSW culture medium was calculated using the computer program PHREEQC with the MinteqV4 database (Parkhurst and Appelo, 2013). For the laboratory experiments, the used dissolved bioavailable $\mathrm{Cu}^{2+}$ concentrations were $1.10^{-4} \mathrm{nM}, 9.10^{-4}$ $\mathrm{nM}, 32.10^{-4} \mathrm{nM}, 12.10^{-3} \mathrm{nM}, 60.10^{-2} \mathrm{nM}, 31 \mathrm{nM}$ for A. catenella and $3.10^{-5} \mathrm{nM}, 9.10^{-4} \mathrm{nM}, 30.10^{-4}$ $\mathrm{nM}, 17.10^{-3} \mathrm{nM}, 32.10^{-3} \mathrm{nM}, 48.10^{-2} \mathrm{nM}$ and $13 \mathrm{nM}$ for $O$. cf. ovata.

\subsubsection{Butyltin measurements}

During the experiment, aliquots were filtered through $0.22 \mu \mathrm{m}$ acetate cellulose filters and acidified with nitric acid Merck Suprapur. The butyltin species, monobutyltin (MBT), dibutyltin (DBT) and tributyltin (TBT), concentrations were measured using a gas chromatograph (Focus GC Thermo Fisher Scientific@) coupled with an inductively coupled plasma mass spectrometer (ICP-MS X Series II-Thermo Fisher Scientific $®)$. Headspace using a polydimethylsiloxane (PDMS) solid-phase microextraction (SPME) was used to preconcentrate the samples. The limit of detection was in the order of pg Sn L ${ }^{-1}$ for the three butyltin species (Briant et al., 2016).

The measured concentrations in the culture media spiked highlighted strong debutylation. Thus, doping initially made with TBT in solution, for concentrations of $0.084,0.27,0.84,2.7,8.4,27$ and $84 \mathrm{nM}$, led to a real initial concentration range from 0.00 to $9 \mathrm{nM}$, including the three forms of 
butyltin: TBT + DBT + MBT. For practical considerations, TBT, DBT and MBT concentrations were pooled together and referred to as butyltin (BuT).

\subsection{Incubation experiments}

Cultures in the exponential growth phase of $A$. catenella and $O$. cf. ovata were used to inoculate sterile flasks each containing $200 \mathrm{~mL}$ of ENSW culture medium to reach a cell density of 500 to 1000 cells $\mathrm{mL}^{-1}$ at $\mathrm{T}_{0}$. The contaminant gradients of $\mathrm{Cu}$ and butyltin were described above. Each experiment was conducted for 7 days, and $1.5 \mathrm{~mL}$ sub-samples were taken daily for the different measurements and observations detailed below. All treatments, including controls, were performed in triplicate.

\subsection{Growth rate measurements and cell morphology observations}

A $100 \mu \mathrm{L}$ aliquot of the sub-sample was fixed with formalin to determine cell abundances in cells $\mathrm{mL}^{-1}$ at days $0,1,2,3$ and 7 . Counting of fixed cells in the microplates was performed with a light microscope (Zeiss AxioVert.A1). Maximum growth rate ( $\mu$ max; expressed in day ${ }^{-1}$ ) was calculated according to Guillard (1973), from the slope of a linear regression over the entire exponential phase of growth by the least square fit of a straight line to the data after logarithmic transformation; $\mu$ max $=\left[\operatorname{Ln}\left(\mathrm{N}_{\mathrm{t}}\right)-\operatorname{Ln}\left(\mathrm{N}_{0}\right) /\left(\mathrm{T}_{\mathrm{t}}-\mathrm{T}_{0}\right)\right]$, with $\mathrm{N}_{0}$ and $\mathrm{N}_{\mathrm{t}}$, cell densities (cells $\mathrm{mL}^{-1}$ ) at the beginning $\left(\mathrm{T}_{0}\right)$ and end $\left(T_{t}\right)$ of the exponential phase, respectively. At day 7 , cell morphology was observed and photomicrographies of cells were taken using a photonic microscope and a camera (ProgRes CF). Growth rate values were used to calculate the $\mathrm{EC}_{50}$, the concentration at which $50 \%$ of control growth rate is reached, according to the Hill (1910) equation, using the Regtox macro for excel developed by Vindimian et al. (1983). 


\subsection{Photosynthetic activity measurements}

The photosynthetic performance was estimated on the basis of the in vivo fluorescence of photosystem II (PSII) of the microalgae. Subsamples of $1.5 \mathrm{~mL}$ were taken at days $0,1,2,3$ and 7 , and the fluorescence was measured with a portable Pulse Amplitude Modulation fluorometer (Aquapen C-APC100, Photon System Instruments), after 30 min of dark adaptation. The maximum quantum yield of photosystem II (Fv/Fm) was calculated following Strasser et al. (2000). Light response curves (LRC) were obtained for $O$. cf. ovata experiments under $\mathrm{Cu}$ and butyltin exposure at days 0, 3 and 7. For LRC, quantum yields (Qy) were measured in response to seven increasing light intensities $\left(10,20,50,100,300,500\right.$ and $1000 \mu \mathrm{mol}$ photons $\left.\mathrm{m}^{-2} \mathrm{~s}^{-1}\right)$ for 60 seconds in each phase. The relative electron transport rate (rETR) was obtained by multiplying Qy by the corresponding irradiance to plot the LRC as rETR against irradiance. From these curves, it was possible to model the photosynthetic parameters $\alpha$ (the maximum light use coefficient), Pmax (rETR max) and Ek (saturating irradiance) using the Platt et al. (1980) equation.

\subsection{Cellular toxin content measurements}

The toxin content and profile of $A$. catenella and $O$. cf. ovata cells were determined at the end of the experiment (day 7) for the control and the following nominal concentrations: $1570 \mathrm{nM}$ of $\mathrm{Cu}$ and $2.7 \mathrm{nM}$ of butyltin. Then, $28 \mathrm{~mL}$ of the culture was sampled in each flask in triplicate and then centrifuged $\left(3000 \times \mathrm{g}, 8 \mathrm{~min}, 4^{\circ} \mathrm{C}\right)$. The supernatant was carefully removed and the culture pellets were frozen at $-20{ }^{\circ} \mathrm{C}$ until the extraction and toxin analyses were performed.

2.6.1 Chemical analysis of paralytic shellfish toxins (PSP) by liquid chromatography/fluorescence detection (LC/FD)

The culture pellets of $A$. catenella were suspended in $1 \mathrm{~mL}$ of $0.1 \mathrm{~N}$ acetic acid. To release the toxins, the samples were sonicated for $5 \mathrm{~min}$ in a water bath three times and centrifuged at $17,000 \times$ $\mathrm{g}$ for $10 \mathrm{~min}$ at $4{ }^{\circ} \mathrm{C}$. The toxin analyses of filtered supernatants were performed using the LC/FD 
PSP toxin analyses method of Van De Riet (2011). The toxins GTXs, dc-GTXs, dc-STXs and STXs were separated by reverse chromatography using a RP column (Zorbax Bonus RP, $3.5 \mu \mathrm{M}, 4.6 \times$ $150 \mathrm{~mm}$ ) with a flow rate of $0.8 \mathrm{~mL} \mathrm{~min}^{-1}$. The C-toxins were separated by a Thermo Beta Basic 8 column $(5 \mu \mathrm{m}, 4.6 \times 250 \mathrm{~mm})$ with a flow rate of $0.8 \mathrm{~mL} \mathrm{~min}{ }^{-1}$. The eluent $\mathrm{pH}$ and/or column temperature were optimized for the separation of some toxins (dc-GTX3/GTX5/dc-GTX-2 \& $\mathrm{C} 1 / \mathrm{C} 2$ ). The toxins were quantified using certified standards provided by CNRC (Halifax, Canada).

2.6.2 Chemical analysis of ovatoxins and palytoxins by liquid chromatography coupled to tandem mass spectrometry (LC-MS/MS)

Toxin extraction from $O$. cf. ovata culture was carried out according to the Amzil procedure (Amzil et al., 2012). The filtered culture pellets were suspended in $1 \mathrm{~mL}$ of methanol/water (1/1). To release the toxins, the samples were sonicated for $40 \mathrm{~min}$, while cooling in an ice bath. The treated sample was centrifuged at $3000 \times g$ at $4{ }^{\circ} \mathrm{C}$ for $15 \mathrm{~min}$. The supernatant was filtered through a 0.2 $\mu \mathrm{m}$ filter, and the toxin profile was determined by LC-MS/MS (Brissard et al., 2014). LC-MS/MS experiments were performed using an LC system (UFLC XR, Shimadzu) coupled to a hybrid triple quadrupole/ion-trap mass spectrometer (API 4000 Qtrap, ABSCIEX). Toxins were separated on a 3 $\mu \mathrm{m}$ C18 Gemini column $(150 \times 2.0 \mathrm{~mm}$, Phenomenex $)$, thermostated at $22{ }^{\circ} \mathrm{C}$ with water (A) and 95\% acetonitrile/water (B), both containing $2 \mathrm{mM}$ ammonium formiate and $50 \mathrm{mM}$ formic acid at a $0.2 \mathrm{~mL} \mathrm{~min}^{-1}$ flow rate. The gradient was raised from $20 \%$ to $100 \% \mathrm{~B}$ in $10 \mathrm{~min}$ and was held over 4 min, before dropping to the initial conditions.

Mass spectrum detection was carried out in multiple reactions monitoring (MRM) mode (positive ions). MRM experiments were established using the following source setting: curtain gas set at 30 psi, ion spray at $5000 \mathrm{~V}$, a turbogas temperature of $300{ }^{\circ} \mathrm{C}$, gas 1 and 2 set at 30 and 40 psi, respectively, and an entrance potential of $10 \mathrm{~V}$. To permit the best toxin identification, each toxin was quantified with three specific transitions (Brissard et al., 2014). Because only the palytoxin 
standard was available, quantitative determination of ovatoxins in extracts was carried out assuming that their molar responses were similar to palytoxin.

\subsection{Statistical analysis}

Data were analyzed using a one-way Anova followed by Tukey's post hoc test, in order to determine any significant differences between treatments in the growth curves and in the toxin content of the cells. Differences were considered significant at p-value $<0.05$. We used Sigmaplot Software (Systat Software Inc).

\section{Results}

\subsection{Measurements of contaminants}

Fig. 1 shows these values at day 7. The nominal and measured concentrations of copper are presented in Fig. 1A on a logarithmic scale. Linear regressions were plotted for each experiment, and equations corresponded to $\mathrm{y}=0.67 \mathrm{x}^{0.95}$ and $\mathrm{y}=0.60 \mathrm{x}^{0.97}$ for the A. catenella and $O$. cf. ovata experiments, respectively. These equations indicated losses of the measured dissolved copper of $33 \%$ and $40 \%$ during the experiments of $A$. catenella and $O$. cf. ovata, respectively. The power index close to 1 showed a linear increase between each concentration. The computed values of the bioavailable $\mathrm{Cu}^{2+}$ are plotted together with the dissolved values for copper using a logarithmic scale in Fig. 1B. Equations of the linear regression indicated a ratio of $10^{5}$ between dissolved values and computed $\mathrm{Cu}^{2+}$. The power index close to 1 revealed a continuous increase of all the tested concentrations, as was expected. The nominal and measured dissolved butyltin concentrations are plotted in Fig. 1C. The measured concentrations were below expected values and showed an increase for the A. catenella and $O$. cf. ovata experiments. Butyltin speciation was also measured for tributyltin (TBT), dibutyltin (DBT) and monobutyltin (MBT) (data not shown). For both experiments, TBT was the dominant form (30\% to $70 \%)$ at $\mathrm{T}_{0}$, while DBT was the dominant form 
(20\% to $80 \%$ ) at $\mathrm{T}_{7}$. Successive debutylation, i.e. sequential dealkylation resulting in dibutyltin (DBT) then monobutyltin (MBT) and finally inorganic tin (TBT $\rightarrow$ DBT $\rightarrow$ MBT $\rightarrow$ Sn) was observed. For practical consideration, the three butyltin forms were pooled together and named here as butyltin (BuT).

\subsection{Effects on growth}

Free dissolved bioavailable $\mathrm{Cu}^{2+}$ values (calculated as described above) were represented for the $\mathrm{Cu}$ experiments, and nominal butyltin values were reported for the BuT experiments. Control cultures of A. catenella reached cell densities of 7000 and 10,500 cells $\mathrm{mL}^{-1}$ for the $\mathrm{Cu}$ and BuT experiments, respectively. Results showed that Copper and BuT had a significant $(\mathrm{p}<0.05)$ negative effect on the growth of both dinoflagellates. These contaminants provoked in A. catenella a threshold-type response (Fig. 2A and 2C). The growth curves indicated limited effects up to $12.10^{-3}$ $\mathrm{nM}$ of $\mathrm{Cu}^{2+}$ and $30.10^{-4} \mathrm{nM}$ of BuT. The growth of this dinoflagellate was reduced significantly ( $\mathrm{p}<0.05$ ) from $0.032 \mathrm{nM}$ of $\mathrm{Cu}^{2+}$ and from $27.10^{-1} \mathrm{nM}$ of BuT, and was completely suppressed for $\mathrm{Cu}^{2+}$ concentrations of $0.6 \mathrm{nM}$ and BuT concentrations of $\geq 27 \mathrm{nM}$ for BuT.

$O$. cf. ovata responses to $\mathrm{Cu}$ and butyltin were different from those of A. catenella, with a significant $(\mathrm{p}<0.05)$ deleterious effect appearing since the first concentrations tested, $3.10^{-5} \mathrm{nM}$ of $\mathrm{Cu}^{2+}$ and $84 \cdot 10^{-3} \mathrm{nM}$ of BuT (Fig. 2B and 2D). O. cf. ovata control cultures showed a lag phase of 2 days, reaching around 3600 cells $\mathrm{mL}^{-1}$ at day 7 for both $\mathrm{Cu}$ and $\mathrm{BuT}$ experiments. The growth of this dinoflagellate was gradually affected, with intermediate effects on the cell density from tested concentrations of $3.10^{-5} \mathrm{nM}$ to $0.017 \mathrm{nM}$ for $\mathrm{Cu}^{2+}$ and from $0.084 \mathrm{nM}$ to $8.4 \mathrm{nM}$ for BuT. Total growth inhibition was induced by concentrations of $\geq 0.48 \mathrm{nM}$ for $\mathrm{Cu}^{2+}$ and $\geq 27 \mathrm{nM}$ for $\mathrm{BuT}_{\text {. }} \mathrm{EC}_{50}$ calculations were derived from the curves linking growth rates to contaminant concentrations using Regtox modelization (Fig. 3). For $\mathrm{Cu}$ exposure, $\mathrm{EC}_{50}$ values were $0.16( \pm 0.09) \mathrm{nM}$ for A. catenella and $0.03( \pm 0.02) \mathrm{nM}$ for $O$. cf. ovata (Fig. 3A). For BuT treatment, the $\mathrm{EC}_{50}$ value was $14.2( \pm 6)$ 
nM for $O$. cf. ovata (Fig. 3B). The $\mathrm{EC}_{50}$ calculation for BuT treatment was not possible for $A$. catenella because of a lack of intermediate values.

\subsection{Cell morphology}

When exposed to 0.6 and $31 \mathrm{nM}\left(\mathrm{Cu}^{2+}\right)$, A. catenella cells were round-shaped, corresponding to temporary cysts (Fig. 4B), which are frequently produced in adverse environmental conditions. Fig 4C shows an uncompleted asexual ecdysis of $A$. catenella temporary cyst (Figueroa et al. 2007). $O$. cf. ovata exposed to concentrations of $\geq 0.03 \mathrm{nM} \mathrm{Cu}^{2+}$ exhibited altered (Fig 4G) thin-walled cysts with dense granular material (Fig. $4 \mathrm{G}$ and $4 \mathrm{H}$ ). Butyltin concentrations of $\geq 8.4 \mathrm{nM}$ provoked severe structural cellular damage in the two dinoflagellates. Cells lost their intracellular organelles and became lytic (Fig. 4D, 4E, 4I and 4J), leading to cell death.

\subsection{Effect on photosynthetic activity}

Maximum quantum yield (Fv/Fm) evolution through time and contaminant exposure is presented in

Fig. 5. Fv/Fm mainly showed a threshold-type response for both organisms exposed to $\mathrm{Cu}$ and BuT. A significant decrease in activity was observed for concentrations above $0.60 \mathrm{nM}\left(\mathrm{Cu}^{2+}\right)$ for $A$. catenella and $0.32 \mathrm{nM}\left(\mathrm{Cu}^{2+}\right)$ for O. cf. ovata (Fig. 5A and 5B). Under BuT exposure, concentrations above $27 \mathrm{nM}$ decreased the Fv/Fm value to reach only $10 \%$ of the control after 2 days of the incubation period (Fig. 5C and 5D).

Photosynthetic-irradiance (PI) curves (rETR against irradiance) were calculated for $O$. cf ovata under $\mathrm{Cu}$ and BuT exposure. Fig. 6 shows the PI curve measured after 7 days of culture in control for two distinct $\mathrm{Cu}$ concentrations $(0.032 \mathrm{nM}$ and $13 \mathrm{nM})$. Exposure to $0.032 \mathrm{nM}\left(\mathrm{Cu}^{2+}\right)$ did not significantly affect the PI curve, with a Pmax of $109( \pm 15.5)$ and $128( \pm 23)$ and an Ek of $148( \pm$ 24) and $169( \pm 30) \mu \mathrm{mol}$ photons $\mathrm{m}^{-2} \mathrm{~s}^{-1}$, respectively. In contrast, the treatment with $13 \mathrm{nM} \mathrm{Cu}^{2+}$ flattened the curve, with a Pmax of $34.6( \pm 1.36)$ and an Ek of $66.1( \pm 10.2) \mu$ mol photons $\mathrm{m}^{-2} \mathrm{~s}^{-1}$. The initial slope of the curve $(\alpha)$, was also affected by the $13 \mathrm{nM} \mathrm{Cu}$ treatment and decreased from 
$0.74( \pm 0.02)$ to $0.53( \pm 0.06)$. Photosynthetic parameters $(\alpha$, Pmax, Ek) were determined from PI curves and plotted against contaminant concentrations at days 0,3 and 7 (Fig. 6). There was an overall tendency for all parameters to decrease when cells were exposed to increasing concentrations of $\mathrm{Cu}$ and BuT. Upon $\mathrm{Cu}$ exposure, above $0.032 \mathrm{nM}\left(\mathrm{Cu}^{2+}\right)$, the $\alpha$ value decreased to 0.55 at days 3 and 7 (Fig. 6A), relative to 0.75 in the control. Similar trends were observed for BuT, with a strong decrease of $\alpha$ ( 0.2 vs 0.7 in the control) for concentrations above $27 \mathrm{nM}$ of BuT (Fig. 6D). The Ek and Pmax parameters followed the same patterns: they decreased as a function of time and contaminant concentration. Moreover, the control value of Ek at day 3 was between 200 and $250 \mu \mathrm{mol}$ photons $\mathrm{m}^{-2} \mathrm{~s}^{-1}$, and decreased to $60 \mu \mathrm{mol}$ photons $\mathrm{m}^{-2} \mathrm{~s}^{-1}$ and $0 \mu \mathrm{mol}$ photons $\mathrm{m}^{-2} \mathrm{~s}^{-1}$ for the highest $\mathrm{Cu}$ and BuT exposures, respectively. The Pmax at day 3 dropped from 210 to 60 when exposed to the highest $\mathrm{Cu}$ concentration (Fig. 6C), and dropped from 240 to 0 at the highest BuT concentration (Fig. 6F).

\subsection{Effect on toxin content}

Ovatoxin-a and ovatoxin-b were detected at $3.64( \pm 0.31)$ pg PITX equivalents cell $^{-1}$ and $1.64( \pm$ 0.16) pg PITX equivalents cell ${ }^{-1}$, respectively, during the $\mathrm{Cu}$ experiment, but ovatoxin-e and $-\mathrm{g}$ were below the detection limit (for both experiments) (Fig. 7). When cells were exposed to $\mathrm{Cu}$ at a concentration of $17.10^{-3} \mathrm{nM}\left(\mathrm{Cu}^{2+}\right)$, the toxin content significantly $(\mathrm{p}<0.05)$ increased to $8.71( \pm$ 1.31) pg PITX equivalents cell ${ }^{-1}$ and $4.55( \pm 0.45)$ pg PITX equivalents cell ${ }^{-1}$ for ovatoxin-a and ovatoxin-b, respectively (Fig. 7A). The BuT treatment $\left(27.10^{-1} \mathrm{nM}\right)$ had no significant effect on ovatoxin-a or ovatoxin-b (Fig. 7B).

PSTs measurements in the $\mathrm{Cu}$ and BuT experiments are presented in Figs 7C and 7D respectively. Toxins GTX6, C3, C4, STX, dc-STX, GTX-2, dc-GTX-2, dc-GTX-3 were not detected, whereas GTX-1 and GTX-5 were detected only in the BuT experiment. The toxins GTX-4, GTX-3, NeoSTX, C1 and C2 were detected in both experiments, with GTX-4 being the most abundant toxin at $2.00 \mathrm{pg} \mathrm{cell}^{-1}$ and $2.82 \mathrm{pg} \mathrm{cell}^{-1}$ in the $\mathrm{Cu}$ and BuT experiments, respectively. The total toxin content 
was enhanced during $\mathrm{Cu}$ exposure (from 2.78 to $4.20 \mathrm{pg} \mathrm{cell}^{-1}$, Fig. $7 \mathrm{C}$ ) and decreased during BuT exposure (from 7.09 to $5.17 \mathrm{pg}$ cell $^{-1}$, Fig. 7D). Under $\mathrm{Cu}$ exposure, the toxin content of GTX-3 and C1 were significantly $(\mathrm{p}<0.05)$ higher than in the control, while GTX-4 was significantly lower during BuT exposure $(\mathrm{p}<0.05)$.

\section{Discussion}

\subsection{Contaminant measurements}

The measured concentrations of dissolved $\mathrm{Cu}$ at the end of the experiment represented $60 \%$ to $68 \%$ of the nominal concentrations, for A. catenella and $O$. cf. ovata, respectively. This loss could be explained by the $\mathrm{Cu}$ adsorption on the culture flasks, but also on the organic particles present in the culture medium and the microalgae themselves (Lage et al., 1996; Franklin et al., 2002). The presence of organic and inorganic dissolved ligands in the culture medium extremely lowered the concentration of bioavailable $\mathrm{Cu}\left(\mathrm{Cu}^{2+}\right)$ (computed $\mathrm{Cu}^{2+} /$ measured dissolved $\mathrm{Cu}=10^{-5}$ ), as has been shown previously (Lage et al., 1996; Sunda, 1989). It is therefore commonly accepted that the toxicity of $\mathrm{Cu}$ must be related to its bioavailable form, $\mathrm{Cu}^{2+}$ (Bruland et al., 2000). Consequently, we only considered the concentrations of the bioavailable $\mathrm{Cu}^{2+}$ for our interpretations. The measured dissolved BuT represented 1 to $10 \%$ of the nominal dissolved concentrations, indicating loss through adsorption and probable change to particulate forms, as shown by White et al., (1999). Speciation of OT as TBT, DBT and MBT was analyzed, and this highlighted classical debutylation of TBT as a function of time, with the dominant form being DBT instead of TBT at the end of the experiment. Dowson et al. (1993) suggested that TBT and MBT tend to go faster in the particulate form compared to DBT. The evolution of the total pool of $\mathrm{Cu}$ and OT during the course of the experiment is rather a complex phenomenon and depends on a wide range of parameters, such as bio-degradation, transformation, adsorption and desorption (Levy et al., 2007; White et al., 1999).

\subsection{Microalgae growth}


$\mathrm{Cu}$ and $\mathrm{BuT}$ inhibited the growth of both dinoflagellates. However, these microalgae responded differently to the tested contaminants. A. catenella showed a threshold-type response, with high cell mortality from $0.60 \mathrm{nM}\left(\mathrm{Cu}^{2+}\right)$ and $27 \mathrm{nM}$ of BuT and a moderate effect below these concentrations (Figs 2A and C). In contrast, $O$. cf. ovata showed a progressive inhibition pattern with increasing concentrations, with significant $(\mathrm{p}<0.05)$ cell mortality rates occurring since the first concentrations tested $\left(3.10^{-5} \mathrm{nM}\right.$ for $\mathrm{Cu}^{2+}$ and $0.084 \mathrm{nM}$ for BuT), indicating a higher sensitivity of these dinoflagellates to these chemicals. Decreasing the cell density in relation to $\mathrm{Cu}$ exposure has been shown for many phytoplankton species (Brand et al., 1986; Ebenezer et al., 2014). The toxicity threshold modes of action of $\mathrm{Cu}$ on $A$. catenella have previously been investigated in the cells of the same species, sampled in Thau Lagoon in France (Herzi et al., 2013), and on other dinoflagellate species (Lage et al., 1994; Saifullah, 1978). Herzi et al. (2013) observed a drastic growth inhibition of A. catenella cells at concentrations of free dissolved $\mathrm{Cu}^{2+}$ above $10.8 \mathrm{nM}$, while in our experiment, significant inhibitory effects on growth were observed at very low concentrations: above $0.60 \mathrm{nM}$ for $A$. catenella, and above $3 \cdot 10^{-5} \mathrm{nM}$ for $O$. cf. ovata. Contrasting in situ $\mathrm{Cu}$ contamination was reported in sediments of Bizerte and Thau Lagoons, at concentrations from 10 to 36 ppm and from 100 to 200 ppm, respectively (El Ati Hellal et al., 2011; Kawakami et al., 2008). Therefore, the higher sensitivity of $A$. catenella studied here from Bizerte Lagoon may be explained by a difference of ecotype, as it is naturally exposed to lower in situ $\mathrm{Cu}$ than the organisms from Thau. This mechanism is corroborated by the pollution-induced community tolerance, which has been shown for numerous metals, including $\mathrm{Cu}$ (Blanck, 2002).

To our knowledge, there is no data on the effect of $\mathrm{Cu}$ and BuT on O. cf. ovata. Our results showed that $O$. cf. ovata was clearly more sensitive to $\mathrm{Cu}$ than $A$. catenella, with a five-fold difference in $\mathrm{EC}_{50}\left(\mathrm{EC}_{50}\right.$ of $0.16 \mathrm{nM}$ and $0.03 \mathrm{nM}$ for $A$. catenella and $O$. cf. ovata, respectively). The normal concentration of dissolved $\mathrm{Cu}$ in seawater is from 1 to $3 \mathrm{nM}$ (Biller and Bruland, 2012; Milne et al., 2010) and, as $99.9 \%$ of dissolved $\mathrm{Cu}$ is considered as complexed and thus not bioavailable to phytoplankton, the $\mathrm{Cu}^{2+}$ concentration in situ is lower (Bruland et al., 2000). In our study, the $\mathrm{Cu}^{2+}$ 
dose response of $O$. cf. ovata suggest that bioavailable $\mathrm{Cu}^{2+}$ concentrations of $3.10^{-2} \mathrm{nM}$ (EC50) could decrease significantly the growth of this toxic dinoflagellate in natural environment. The measured $\mathrm{Cu}^{2+}$ concentrations in the Atlantic Ocean is from $10^{-5} \mathrm{nM}$ to $10^{-4} \mathrm{nM}$ (Bruland et al., 2000; Jacquot and Moffett, 2015)". Many mechanisms allow phytoplankton to resist and detoxify toxic metals, among which the exudation of organic content to chelate and bind toxic ions (Megharaj et al., 2003; Worms et al., 2006). This was demonstrated for A. catenella, which secretes polysaccharides in the presence of $\mathrm{Cu}$ (Herzi et al., 2013). Defence mechanisms probably explain the relatively efficient resistance of $A$. catenella to $\mathrm{Cu}$ in comparison with $O$. cf. ovata. It is possible that metal availability in situ could play a role in the development of this HAB species.

Compared to $\mathrm{Cu}$, organotin studies have mainly focused on fishes and macro-invertebrates, showing the disruption of oyster and neo-gastropod reproduction (for example Gibbs and Bryan, 1986). Organotin can also delay hatching, reduce survival and alter the morphology of fishes (Fent, 1996; Fent and Meier, 1994). On the other hand, studies targeting phytoplankton remain scarce, as mentioned by Petersen and Gustavson (2000). Organotin has been shown to be a potent toxic agent for some microorganisms by disrupting the cellular membrane of marine bacteria (Laurence et al., 1989) and by altering photosynthesis in the microalgae Dunaliella tertiolecta and Skeletonema costatum (Mooney and Patching, 1995). In our study, as observed for $\mathrm{Cu}, O$. cf. ovata was more sensitive to BuT than A. catenella, with cell density decreasing from $0.084 \mathrm{nM}$ (corresponding to $0.01 \mu \mathrm{g} \mathrm{L}^{-1}$ ) for $O$. cf. ovata with an $\mathrm{EC}_{50}$ of $14.2( \pm 6) \mathrm{nM}$ (corresponding to an $\mathrm{EC}_{50}$ of $1.42 \mu \mathrm{g} \mathrm{L}^{-}$ ${ }^{1}$ ) and from $27 \mathrm{nM}$ (corresponding to $3.2 \mu \mathrm{g} \mathrm{L}^{-1}$ ) for A. catenella. These results are in agreement with previous studies on the green algae Ankistrodesmus falcatus ( $\mathrm{EC}_{50}$ of $5 \mu \mathrm{g} \mathrm{L}^{-1}$ in Wong et al., 1982) and on two diatoms Skeletonema costatum and Thalassiosira pseudonana with tribultyltin acetate, showing $\mathrm{EC}_{50}$ values of $0.36 \mu \mathrm{g} \mathrm{L}^{-1}$ and $1.28 \mu \mathrm{g} \mathrm{L}^{-1}$, respectively (Walsh et al., 1985). The cell density of Pavlova lutheri, Dunaliella tertiolecta and Skeletonema costatum were also affected when exposed to values of $3 \mu \mathrm{g} \mathrm{L}^{-1}$ of TBT (as oxide) (Beaumont and Newman, 1986). Butyltin concentrations in seawater are reported from 10 to $100 \mathrm{ng} \mathrm{L}^{-1}$ (Antizar-Ladislao, 2008; Thomaidis 
et al., 2007). The BuT dose response observed for the $O$. cf. ovata cell density in our study suggests potential inhibitory effects on this benthic dinoflagellate species in contaminated marine environments.

In our study, the benthic $O$. cf. ovata was more sensitive to $\mathrm{Cu}$ and $\mathrm{BuT}$ than the planktonic $A$. catenella. On the basis of an in situ study, Wood et al. (1983) highlighted that coastal phytoplankton took advantage of $\mathrm{Cu}$-complexing agents present in coastal waters, and thus showed better tolerance to $\mathrm{Cu}$ in comparison to oceanic communities. However, to our knowledge, no studies were performed to compare planktonic to benthic species sensitivities to metals. Sediment is recognized to be a pollution sink with long residence time of organotins and $\mathrm{Cu}$ (Long et al., 1995). It has been demonstrated that toxicity of $\mathrm{Cu}$ and organotins is strongly correlated with binding agents and chelating molecules (White et al., 1999; Bruland et al., 2000). In addition, studies on sediment showed that interstitial water from sediment would enrich the surrounding seawater with organic ligands (Sakellari et al., 2011), while any $\mathrm{Cu}$ fluxing from the sediments to the water column is likely to be organically complexed (Skrabal et al., 1997). Some studies of sediment toxicity showed that metal toxicity is related to the bioavailable part and not the total metal concentration (Gillan et al., 2005; Simpson et al., 2004). Macroalgae produce exudates with $\mathrm{Cu}$ binding properties. Hence, Vasconcelos and Leal (2001) showed a stimulation in the production of two chelating molecules, cysteine- and glutathione-like by the green macroalgae Enteromorpha spp. when it was exposed to $\mathrm{Cu}$. One can suppose that the potentially important deleterious effect of $\mathrm{Cu}$ and organotins on microalgae in some highly contaminated ecosystems could be reduced due to the presence of chelating molecules in the benthic habitats. This could explain the apparent reduced defense mechanisms against metals observed for $O$. cf. ovata, which thrives in close relationships with sediment and macroalgae.

$\mathrm{Cu}$ has been suggested as a selecting force for organisms in planktonic communities because of the different sensitivities to this metal between phylogenetic groups (Brand et al., 1986; Pistocchi et al., 2000). The most recent studies used artificial sea water medium in their experiments, which affects 
the $\mathrm{Cu}^{2+}$ activity in comparison to natural sea water (Metaxas and Lewis, 1991), while almost $70 \%$ of published studies do not measure the $\mathrm{Cu}$ introduced in the batch-cultures (Leal et al., 2016). In addition, most studies have not taken into account the bioavailable $\mathrm{Cu}^{2+}$, making inter-study comparisons difficult to make. Brand et al. (1986) used similar experimental conditions to the present study, and we consequently used their $\mathrm{EC}_{50}$ values for comparison with our $\mathrm{EC}_{50}$ values obtained for $O$. cf. ovata and A. catenella contaminated with $\mathrm{Cu}$ (Fig. 8). We observed that $O$. cf. ovata sensitivity is in the range of other dinoflagellates ( $\mathrm{pCu}$ from 10.5 to 10.64), whereas $A$. catenella appeared to be more tolerant than other dinoflagellates and diatoms. In the context of the increasing anthropization of marine environments, particularly in confined waters (e.g. harbours or lagoons), where A. catenella forms recurrent blooms (Fertouna-Bellakhal et al., 2015; Laanaia et al., 2013), this dinoflagellate could potentially take advantage of this higher tolerance to contaminants in impacted marine ecosystems.

\subsection{Cell morphology}

We observed an effect of $\mathrm{Cu}$ on the contaminated microalgae, with an increase in the number of round thin-walled cells (Accoroni et al. 2015) acting as temporary cysts and showing and showing for some of them morphological alterations (Fig. 4G). These cell forms were observed at $\mathrm{Cu}^{2+}$ concentrations of $\geq 0.032 \mathrm{nM}$ and $0.60 \mathrm{nM}$ for $O$. cf. ovata and A. catenella, respectively. A similar effect was shown for A. catenella (Herzi et al., 2013) and Amphidinium cartarae (Lage et al., 2001) when exposed to $\mathrm{Cu}$. BuT induced mortality of the A. catenella cells, which showed severe disintegration and membrane lysis at concentrations of $\geq 27 \mathrm{nM}$. When $O$. cf. ovata was exposed to BuT concentrations of $\geq 8.4 \mathrm{nM}$, an increasing number of cells lost their intracellular organelles and became lytic. BuTs could impact membrane integrity because of their lipophilicity, binding or being inserted into the cellular membrane and disrupting its integrity and thus the activity of the numerous related enzymes (White et al., 1999). For example, the membrane enzymes ATPase, NADH oxidase, ß-galactosidase and alkaline phosphatase were inhibited by TBT in various bacteria, such 
as Bacillus (Cooney and Wuertz, 1989; Tseng and Cooney, 1995). The resulting damage to the cellular membrane could lead to higher permeability inducing, for example, the release of $\mathrm{K}^{+}$ (Laurence et al., 1989; Tobin and Cooney, 1999). The increase in permeability of the cell membrane leads to a higher diffusion of the pollutants throughout the cytoplasm, increasing their lethal effect.

\subsection{Photosynthetic activity}

The results showed that the maximum quantum yields of photosynthesis (Fv/Fm) for both species showed sensitivity to high $\mathrm{Cu}(\geq 0.60 \mathrm{nM})$ and $\mathrm{BuT}(\geq 27 \mathrm{nM})$ exposure (Fig. 5). A decrease in Fv/Fm has been well documented for phytoplankton species exposed to $\mathrm{Cu}$, indicating that $\mathrm{Cu}$ results in the closing of the reaction centers, thus decreasing photochemistry capacity (Juneau et al., 2002; Miao et al., 2005). $\mathrm{Cu}$ is able to substitute the $\mathrm{Mg}^{2+}$ atom in the chlorophyll molecule, a process that decreases the fluorescence quantum yield (Küpper et al., 1998, 1996). $\mathrm{Cu}^{2+}$ ions can also affect the PSII oxidizing side by an interaction with the PSII primary electron donor, the $\mathrm{Tyr}_{\mathrm{z}}$ component (Samson et al., 1988), and they can affect the rate of QA-QB oxidoreduction (Yruela et al., 1992; Jegerschold et al. 1995). This metal greatly influences the PSII electron transport pathway by interfering with lipid and pigment biosynthesis, and as a consequence, the general chloroplast structure becomes altered (Baron et al., 1995). A recent study by Guo et al. (2016) showed a regulation of genes implied in the photosystem maintenance of Prorocentrum minimum in response to the biocide $\mathrm{Cu}$ sulfate. Moreover, the modulation of the proteome was also observed under zinc or lead stress for the dinoflagellate A. catenella (Jean et al., 2017). This study found that the expression of most proteins was downregulated, including those involved in photosynthesis and the oxidative stress response.

To our knowledge, butyltin (including MBT, DBT and TBT) studies on the photosynthetic activity of phytoplankton are scarce in the literature and no study was performed on dinoflagellates, although this phytoplankton group represents up to $80 \%$ of HAB species and constitutes an 
important component of the autotrophic compartment. Yong et al. (2007) showed a decrease in the photosynthetic pigment content on the chlorophycea Tetraselmis suecica exposed to TBT, while primary production and cell density of Ankistrodesmus falcatus were also lowered (Wong et al., 1982). A decrease of primary production has also been reported in the natural phytoplankton assemblage in mesocosm experiments in the presence of TBT (Arrhenius et al., 2006; Petersen and Gustavson, 1998).

When examining the effects of $\mathrm{Cu}$ and BuT concentrations on A. catenella photosynthetic activity, the evolution matched with the negative effect of these contaminants on growth at the highest tested concentrations. However, for $O$. cf. ovata, growth was inhibited at $3.10^{-5} \mathrm{nM}\left(\mathrm{Cu}^{2+}\right)$ and $0.084 \mathrm{nM}$ of BuT, in contrast to the Fv/Fm inhibition, which occurred at much higher concentrations $(0.032$ $\mathrm{nM}$ of $\mathrm{Cu}^{2+}$ and $27 \mathrm{nM}$ of BuT), showing a photochemistry tolerance to both contaminants. The PSII activity was considered as a good indicator of stress induced by this metal, as it is a target of $\mathrm{Cu}$ (Juneau et al., 2002; Protopopov et al., 2015). This is in contrast with our results, showing that growth of $O$. cf. ovata is a more sensitive bio-indicator both for $\mathrm{Cu}$ and BuT effects. This conclusion is supported by Cid et al. (1995) and Fisher et al. (1981), who found that, for the diatoms Asterionella japonica and Phaeodactylum tricornutum, growth was more sensitive to the $\mathrm{Cu}$ effect than the photosynthesis response. $\mathrm{Cu}$ and other metals can inhibit cell division mechanisms without affecting photosynthesis (Stauber and Florence, 1987). This discrepancy might be explained by the metal inhibition on methionine production, stopping cell division without consequences for photosynthesis (Davies, 1976).

We investigated the effects of $\mathrm{Cu}^{2+}$ and $\mathrm{BuT}$, using a light response curve protocol, on PI curve parameters, such as $\alpha$, Pmax and Ek of $O$. cf. ovata, to highlight the specific mechanism and/or structure of the photosynthetic apparatus was targeted. The decrease of the measured parameters suggested a clear disturbance effect on the rETR inside the PSII. The rETR parameters were affected at the same concentrations as Fv/Fm for both contaminants. The decrease in energy transfer from the antennae to the reaction center in the PSII was previously observed in $\mathrm{Cu}$-stressed 
Senedesmus obliquus cells (Mallick and Mohn, 2003). This corresponds with the clear decline of the $\alpha$ parameter, indicating a lowered efficiency of light capture (Ralph and Gademann, 2005), which indicates damage on the photosynthetic antenna. The decline of Ek indicates a lowering of the saturating irradiance, while the decrease of Pmax is consistent with the decline of the Fv/Fm value discussed previously. Tin had a stronger inhibitive action than $\mathrm{Cu}$ on $\alpha$, and entirely disrupted Ek and Pmax, indicating a strong deleterious effect on the PSII general structure. Our results clearly showed that light transport through PSII was strongly affected by both contaminants in this dinoflagellate species and impacting its photosynthetic performances. Contaminants decreased photosynthetic activities, and thus the observed decrease for $\alpha$ values may severely impact the competition for light with other microalgae (Huisman et al., 1999).

\subsection{Toxins}

Toxin contents of $O$. cf. ovata and A. catenella cells in the control condition were consistent with other isolates from the Mediterranean sea (Ben-Gharbia et al., 2016; Laabir et al., 2013). $\mathrm{Cu}$ and BuT had contrasting effects on the toxin content of $A$. catenella and $O$. cf. ovata. Exposing $A$. catenella cells to $0.012 \mathrm{nM}$ of $\mathrm{Cu}^{2+}$ increased GTX-3 and $\mathrm{C} 1$ paralytic shellfish toxin content. Butyltin had no clear effect on neither ovatoxin nor paralytic shellfish toxin concentrations. There was a significant increase in ovatoxin-a and -b in $O$. cf. ovata cells exposed to $0.017 \mathrm{nM}$ of $\mathrm{Cu}^{2+}$, raising the total ovatoxin content from $5.28 \mathrm{pg}$ PITX equivalents cell ${ }^{-1}$ to $13.26 \mathrm{pg}$ PITX equivalents cell $^{-1}$. To our knowledge, studies of metal stress effects on phytoplankton toxin production are scarce, and no work has examined the potential effect of $\mathrm{Cu}$ and $\mathrm{BuT}$ on toxin production by dinoflagellate species. However, it was shown that a selenium-repleted condition could increase yessotoxin production in the dinoflagellate Protoceratium reticulatum (Mitrovic et al., 2004), whereas the domoic acid production of the diatom Pseudo-nitzschia increased significantly in response to $\mathrm{Cu}$-stressed conditions (Maldonado et al., 2002). Here, the toxin content increase when cells were exposed to $0.017 \mathrm{nM}$ of $\mathrm{Cu}^{2+}$ was concomitant to the cell density decrease. Future work 
could analyze the chelating properties of these toxins to determine whether this production could lower the $\mathrm{Cu}$ stress, as was found for diatoms, with domoic acid having a potential action on trace metals (Rue and Bruland, 2001). Cellular pathways, such as gene expression and protein regulation should be studied to better understand this increase in toxin production in response to $\mathrm{Cu}^{2+}$ stress. Here, the reported results concerning the effect of $\mathrm{Cu}$ and $\mathrm{BuT}$ on toxin content (pg.cell ${ }^{-1}$ ) of the studied microalgae are related to intracellular fraction of toxins. It will be interesting in a future work to consider the toxins released extracellularly (Pezzolesi et al., 2016) to bring information on the entire amount of toxins produced by the algae especially since the pollutants tested and particularly the butyltin causes cell lysis. Complementary experiments have to consider the estimation of the specific toxin production ( $\mu$ tox) of the two studied dinoflagellates grown with the pollutants (Basti et al. 2015).

\section{Conclusion}

This study demonstrated the higher tolerance of the planktonic A. catenella to $\mathrm{Cu}$ and butyltin compared to the benthic $O$. cf. ovata. However, both dinoflagellate species were negatively impacted in their physiology by the tested chemicals at specific concentrations. Calculations of $\mathrm{EC}_{50}$ indicated a usual $\mathrm{Cu}^{2+}$ sensitivity for $O$. cf. ovata compared to other dinoflagellates, while the sensitivity of A. catenella was comparable to a more tolerant group (diatoms). These differences in sensitivity from organisms of different marine compartments could suggest a contrasting habitat effect in protecting them in situ, through chelating properties or other unknown mechanisms. Butyltin exposure led to cell death, and $\mathrm{Cu}^{2+}$ was shown to induce cyst formation at the highest concentration prior to cell death. $\mathrm{Cu}^{2+}$ at $0.012 \mathrm{nM}$ increased the ovatoxin content of $O$. cf. ovata, while cell density was decreased. The chelating properties of ovatoxins on metal ions should be investigated to identify a potential role in regulating ambient metal concentrations and bioavailability. The increase of intracellular ovatoxin concentrations in response to $\mathrm{Cu}^{2+}$ exposure 
could pose a supplementary health and socio-economic threat in coastal areas with metal contamination, where HAB species develop.

\section{Conflict of interest}

There are no any conflicts of interest.

\section{ACKNOWLEDGEMENTS}

This work was supported by the LMI COSYSMED (Laboratoire Mixte International Contaminants et Ecosystèmes Marins Sud Méditerranéens) belonging to IRD (Institut de Recherche pour le Développement), and LAGUNOTOX project funded by Fondation TOTAL. We would also like to thank the IRD and French Ministry of Foreign Affairs for funding Douglas Couet in Tunisia in the framework of International Volunteers Program. 


\section{References}

Abidli, S., Lahbib, Y., González, P.R., Alonso, J.I.G., Trigui El Menif, N., 2015. Butyltin compounds in sediment and biota from the lagoon of Bizerte (northern Tunisia): Potential risk for consumers?. Hum. Ecol. Risk Assess. An Int. J. 22, 337-349.

Accoroni, S., Romagnoli, T., Colombo, F., Pennesi, C., Gioia, C., Camillo, D., Marini, M., Battocchi, C., Ciminiello, P., Dell, C., Dello, E., Fattorusso, E., Tartaglione, L., Penna, A., Totti, C., 2011. Ostreopsis cf . ovata bloom in the northern Adriatic Sea during summer 2009 : Ecology, molecular characterization and toxin profile. Mar. Pollut. Bull. 62, 2512-2519.

Accoroni, S., Romagnoli, T., Pichierri, S., Totti, C., 2014. New insights on the life cycle stages of the toxic benthic dinoflagellate Ostreopsis cf. ovata. Harmful. Algae. 34, 7-16.

Alzieu, C., Sanjuan, J., Deltreil, J.P., Borel, M., 1986. Tin Contamination in Arcachon Bay:

Effects on Oyster Shell Anomalies. Mar. Pollut. Bull. 17, 494-498,

Alzieu, C., Michel, P., Tolosa, I., Bacci, E., Mee, L.D., Readman, J.W., 1991. Organotin compounds in the Mediterranean: A continuing cause for concern. Mar. Environ. Res. 32, 261270.

Amzil, Z., Sibat, M., Chomerat, N., Grossel, H., Marco-Miralles, F., Lemee, R., Nezan, E., Sechet, V., 2012. Ovatoxin-a and palytoxin accumulation in seafood in relation to Ostreopsis cf. ovata blooms on the French Mediterranean coast. Mar. Drugs 10, 477-496.

Anderson, D.M., Cembella, A.D., Hallegraeff, G.M., 2012. Progress in understanding Harmful Algal Blooms: Paradigm shifts and new technologies for research, monitoring, and management. Ann. Rev. Mar. Sci. 4, 143-176.

Antizar-Ladislao, B., 2008. Environmental levels, toxicity and human exposure to tributyltin (TBT)-contaminated marine environment, a review. Environ. Int. 34, 292-308.

Arrhenius, Å., Backhaus, T., Grönvall, F., Junghans, M., Scholze, M., Blanck, H., 2006. Effects of three antifouling agents on algal communities and algal reproduction: Mixture toxicity studies 
with TBT, Irgarol, and Sea-Nine. Arch. Environ. Contam. Toxicol. 50, 335-345.

Baron, M., Arellano, J.B., Gorge, J.L., 1995. Copper and Photosystem-Ii - a controversial relationship. Physiol. Plant. 94, 174-180.

Basti, L., Uchida, H., Matsushima, R., Watanabe, R., Suzuki, T., Yamatogi, T., Nagai, S., 2015. Influence of Temperature on Growth and Production of Pectenotoxin-2 by a Monoclonal Culture of Dinophysis caudata. Mar. Drugs. 13, 7124-7137.

Beaumont, A.R., Newman, P.B., 1986. Low levels of tributyl tin reduce growth of marine microalgae. Mar. Pollut. Bull. 17, 457-461.

Ben-Gharbia, H., Yahia, O.K.D., Amzil, Z., Chomérat, N., Abadie, E., Masseret, E., Sibat, M., Triki, H.Z., Nouri, H., Laabir, M., 2016. Toxicity and growth assessments of three thermophilic benthic dinoflagellates (Ostreopsis cf. ovata, Prorocentrum lima and Coolia monotis) developing in the Southern Mediterranean basin. Toxins. 8, 1-38.

Berdalet, E., Fleming, L.E., Gowen, R., Davidson, K., Hess, P., Backer, L.C., Moore, S.K., Hoagland, P., Enevoldsen, H., 2016. Marine harmful algal blooms, human health and wellbeing: challenges and opportunities in the $21^{\text {st }}$ century. J. Mar. Biol. Assoc. U.K.. 2015,

Bettin, C., Oehlmann, J., Stroben, E., 1996. TBT-induced imposex in marine neogastropods is mediated by an increasing androgen level. Helgoländer. Meeresuntersuchungen. 50, 299-317.

Biller, D. V., Bruland, K.W., 2012. Analysis of Mn, Fe, Co, Ni, Cu, Zn, Cd, and Pb in seawater using the Nobias-chelate PA1 resin and magnetic sector inductively coupled plasma mass spectrometry (ICP-MS). Mar. Chem. 130-131, 12-20.

Blanck, H., 2002. A critical review of procedures and approaches used for assessing pollutioninduced community tolerance (PICT) in biotic communities. Hum. Ecol. Risk Assess. 8, 10031034.

Brand, L.E., Sunda, W.G., Guillard, R.R.L., 1986. Reduction of marine phytoplankton reproduction rates by copper and cadmium. J. Exp. Mar. Bio. Ecol. 96, 225-250.

Bravo, I., Vila, M., Casabianca, S., Rodriguez, F., Rial, P., Riobo, P., Penna, A., 2012. Life cycle 
stages of the benthic palytoxin-producing dinoflagellate Ostreopsis cf. ovata (Dinophyceae). Harmful. Algae.18 (0), 24-34.

Briant, N., Bancon-Montigny, C., Freydier, R., Delpoux, S., Elbaz-Poulichet, F., 2016. Behaviour of butyltin compounds in the sediment pore waters of a contaminated marina (Port Camargue, South of France). Chemosphere. 150, 123-129.

Brissard, C., Herrenknecht, C., Séchet, V., Hervé, F., Pisapia, F., Harcouet, J., Lémée, R., Chomérat, N., Hess, P., Amzil, Z., 2014. Complex toxin profile of French Mediterranean Ostreopsis cf. ovata strains, seafood accumulation and ovatoxins prepurification. Mar. Drugs. 12, 2851-2876.

Bruland, K.W., Rue, E.L., Donat, J.R., Skrabal, S.A., Moffett, J.W., 2000. Intercomparison of voltammetric techniques to determine the chemical speciation of dissolved copper in a coastal seawater sample. Anal. Chim. Acta. 405, 99-113.

Cid, A., Herrero, C., Torres, E., Abalde, J., 1995. Copper toxicity on the marine microalga Phaeodactylum tricornutum: effects on photosynthesis and related parameters. Aquat. Toxicol. $31,165-174$.

Cooney, J., Wuertz, S., 1989. Toxic effects of tin compounds on microorganisms. J. Ind. Microbiol. $375-402$.

Cooney, J.J., Rome, L., Laurence, O., Gadd, G.M., 1989. Effects of organotin and organolead compounds on yeasts. J. Ind. Microbiol. 4, 279-288.

Cossa, D., Fanget, A., Chiffoleau, J., Bassetti, M., Buscail, R., Dennielou, B., Briggs, K., Arnaud, M., Guédron, S., Berné, S., 2017. Progress in Oceanography Chronology and sources of trace elements accumulation in the Rhône pro-delta sediments (Northwestern Mediterranean) during the last 400 years. Prog. Oceanogr. In press.

Davidson, K., Gowen, R.J., Harrison, P.J., Fleming, L.E., Hoagland, P., Moschonas, G., 2014. Anthropogenic nutrients and harmful algae in coastal waters. J. Environ. Manage. 146, 206216. 
Davies, A.G., 1976. An assessment of the basis of mercury tolerance in Dunaliella tertiolecta. J. mar. biol. Ass. U.K. 56, 39-57.

Díez, S., Ábalos, M., Bayona, J.M., 2002. Organotin contamination in sediments from the Western Mediterranean enclosures following 10 years of TBT regulation. Water. Res. 36, 905-918.

Dowson, P.H., Bubb, J.M., Lester, J.N., 1993. Depositional profiles and relationships between organotin compounds in freshwater and estuarine sediment cores. Environ. Monit. Assess. 28, $145-160$.

Ebenezer, V., Lim, W.A., Ki, J., 2014. Effects of the algicides $\mathrm{CuSO} 4$ and $\mathrm{NaOCl}$ on various physiological parameters in the harmful dinoflagellate Cochlodinium polykrikoides. J. Appl. Phycol. 26, 2357-2365.

El Ati Hellal, M., Hellal, F., El Khemissi, Z., Jebali, R., Dachraoui, M., 2011. Trace metals in algae and sediments from the north-eastern Tunisian lagoons. Bull. Environ. Contam. Toxicol. 86, 194-198.

Etheridge, S.M., Roesler, C.S., 2005. Effects of temperature, irradiance, and salinity on photosynthesis, growth rates, total toxicity, and toxin composition for Alexandrium fundyense isolates from the Gulf of Maine and Bay of Fundy. Deep. Res. Part II Top. Stud. Oceanogr. 52, 2491-2500.

Fent, K., 1996. Ecotoxicology of organotin compounds. Crit. Rev. Toxicol. 26, 1-117.

Fent, K., Meier, W., 1994. Effects of triphenyltin on fish early life stages. Arch. Environ. Contam. Toxicol. 27, 224-231.

Fertouna-Bellakhal, M., Dhib, A., Fathalli, A., Bellakhal, M., Chomérat, N., Masseret, E., Laabir, M., Turki, S., Aleya, L., 2015. Alexandrium catenella Litaker sp. nov (Group IV): Resting cyst distribution and toxin profile of vegetative cells in Bizerte Lagoon (Tunisia, Southern Mediterranean Sea). Harmful. Algae. 48, 69-82.

Figueroa, R.I., Garcés, E., Bravo, I., 2007. Comparative study of the life cycles of Alexandrium tamutum and Alexandrium minutum (Gonyaulacales, Dinophyceae) in culture1. J. Phycol. 43, 
1039-1053.

Fisher, N.S., Jones, G.J., Nelson, D.M., 1981. Effects of copper and zinc on growth, morphology, metabolism of. J. Exp. Mar. Biol. Ecol. 51, 37-56.

Flouty, R., Estephane, G., 2012. Bioaccumulation and biosorption of copper and lead by a unicellular algae Chlamydomonas reinhardtii in single and binary metal systems: A comparative study. J. Environ. Manage. 111, 106-114.

Fortibuoni, T., Noventa, S., Rampazzo, F., Gion, C., Formalewicz, M., Berto, D., Raicevich, S., 2013. Evidence of butyltin biomagnification along the northern Adriatic food-web (Mediterranean Sea) elucidated by stable isotope ratios. Environ. Sci. Technol. 47, 3370-3377.

Gibbs, P.E., Bryan, G.W., 1986. Reproductive Failure in Populations of the Dog-Whelk, Nucella Lapillus, Caused by Imposex Induced by Tributyltin from Antifouling Paints. J. Mar. Biol. Assoc. UK. 66(4), 767-777.

Gillan, D.C., Danis, B., Pernet, P., Joly, G., Dubois, P., 2005. Structure of sediment-associated microbial communities along a heavy-metal contamination gradient in the marine environment. Appl. Environ. Microbiol. 71, 679-690.

Guo, R., Lim, W.A., Ki, J.S., 2016. Genome-wide analysis of transcription and photosynthesis inhibition in the harmful dinoflagellate Prorocentrum minimum in response to the biocide copper sulfate. Harmful. Algae. 57, 27-38.

Hallegraeff, G.M., 1993. A review of harmful algal blooms and their apparent global increase. Phycologia. 32, 79-99.

Hanana, H., Simon, G., Kervarec, N., Cérantola, S., 2014. Evaluation of toxicological effects induced by tributyltin in clam Ruditapes decussatus using high-resolution magic angle spinning nuclear magnetic resonance spectroscopy: Study of metabolic responses in heart tissue and detection of a novel metabolite. Toxicol. Rep. 1, 777-786.

Hänsch, R., Mendel, R.R., 2009. Physiological functions of mineral micronutrients (Cu, Zn, Mn, Fe, Ni, Mo, B, Cl). Curr. Opin. Plant. Biol. 12, 259-266. 
Harrison, P.J., Waters, R.E., Taylor, F.J.R., 1980. A broad Spectrum Artificial Sea Water Medium for Coastal and Open Ocean Phytoplankton. J. Phycol. 16, 28-35.

Hartwell, S.I., Apeti, D.A., Mason, A.L., Pait, A.S., 2016. An Assessment of Tributyltin and Metals in Sediment Cores from the St. Thomas East End Reserves. NOAA Technical Memorandum NOS NCCOS 217. Silver Spring, MD. 20 pp.

Herzi, F., Jean, N., Zhao, H., Mounier, S., Mabrouk, H.H., Hlaili, A.S., 2013. Copper and cadmium effects on growth and extracellular exudation of the marine toxic dinoflagellate Alexandrium catenella: 3D-fluorescence spectroscopy approach. Chemosphere. 93, 1230-1239.

Hill, A., 1910. The possible effects of the aggregation of the molecules of haemoglobin on its dissociation curves. J Physiol. 40, 4-7.

Huisman, J., Jonker, R.R., Zonneveld, C., Weissing, F.J., 1999. Competition for Light between Phytoplankton Species: Experimental Tests of Mechanstic Theory. Ecology. 80, 211-222.

Jacquot, J.E., Moffett, J.W., 2015. Copper distribution and speciation across the International Geotraces Section GA03. Deep. Res. Part II Top. Stud. Oceanogr. 116, 187-207.

Jansson, H., Ökvist, M., Jacobson, F., Ejdebäck, M., Hansson, Ö., Sjölin, L., 2003. The crystal structure of the spinach plastocyanin double mutant G8D/L12E gives insight into its low reactivity towards photosystem 1 and cytochrome f. Biochim. Biophys. Acta - Bioenerg. 1607, 203-210.

Jean, N., Dumont, E., Herzi, F., Balliau, T., Laabir, M., Masseret, E., Mounier, S., 2017. Modifications of the soluble proteome of a mediterranean strain of the invasive neurotoxic dinoflagellate Alexandrium catenella under metallic stress conditions. Aquat. Toxicol. 188, $80-91$.

Jegerschold, C., Arellano, J.B., Schroder, W.P., Van Kan, P.J.M., Baron, M., Styring, S., 1995. Copper(II) inhibition of electron transfer through photosystem II studied by EPR spectroscopy. Biochemistry 34, 12747-12754.

Juneau, P., El Berdey, A., Popovic, R., 2002. PAM fluorometry in the determination of the 
sensitivity of Chlorella vulgaris, Selenastrum capricornutum, and Chlamydomonas reinhardtii to copper. Arch. Environ. Contam. Toxicol. 42, 155-164.

Kawakami, S.K., Seidel, J.-L., Elbaz-Poulichet, F., Achterberg, E.P., 2008. Trace-Metal Biogeochemistry in the Mediterranean Thau Lagoon, a Shellfish Farming Area. J. Coast. Res. 4, 194-202.

Küpper, H., Küpper, F., Spiller, M., 1998. In situ detection of heavy metal substituted chlorophylls in water plants. Photosynth. Res. 58, 123-133.

Küpper, H., Küpper, F., Spiller, M., 1996. Environmental relevance of heavy metal-substituted chlorophylls using the example of water plants. J. Exp. Bot. 47, 259-266.

Kwok, K.W.H., Leung, K.M.Y., 2005. Toxicity of antifouling biocides to the intertidal harpacticoid copepod Tigriopus japonicus (Crustacea, Copepoda): Effects of temperature and salinity. Mar. Pollut. Bull. 51(8), 830-837.

Laabir, M., Collos, Y., Masseret, E., Grzebyk, D., Abadie, E., Savar, V., Sibat, M., Amzil, Z., 2013. Influence of environmental factors on the paralytic shellfish toxin content and profile of Alexandrium catenella (Dinophyceae) isolated from the Mediterranean Sea. Mar. Drugs. 11, $1583-1601$.

Laanaia, N., Vaquer, A., Fiandrino, A., Genovesi, B., Pastoureaud, A., Cecchi, P., Collos, Y., 2013. Wind and temperature controls on Alexandrium blooms (2000-2007) in Thau lagoon (Western Mediterranean). Harmful. Algae. 28, 31-36.

Lage, O.M., Parente, A.M., Soares, H.M.V.M., Vasconcelos, M.T.S.D., Salema, R., Parente, A.M., Soares, H.M.V.M., Vasconcelos, M.T.S.D., 1994. Some effects of copper on the dinoflagellates Amphidinium carterae and Prorocentrum micans in batch culture. Eur. J. Phycol. 29(4) 253-260.

Lage, O.M., Sansonetty, F., O’Connor, J.E., Parente, a M., 2001. Flow cytometric analysis of chronic and acute toxicity of copper(II) on the marine dinoflagellate Amphidinium carterae. Cytometry. 44, 226-235. 
Lage, O.M., Soares, H.M.V.M., Vasconcelos, M.T.S.D., Parente, a M., Salema, R., 1996. Toxicity effects of copper (II) on the marine dinoflagellate Amphidinium carterae: influence of metal speciation. Eur. J. Phycol. 31, 341-348.

Lapointe, B.E., Herren, L.W., Debortoli, D.D., Vogel, M.A., 2015. Evidence of sewage-driven eutrophication and harmful algal blooms in Florida's Indian River Lagoon. Harmful. Algae. $43,82-102$.

Laurence, O.S., Cooney, J.J., Gadd, G.M., 1989. Toxicity of organotins towards the marine yeast Debaryomyces hansenii. Microb. Ecol. 17, 275-285.

Leal, P.P., Hurd, C.L., Sander, S.G., Armstrong, E., Roleda, M.Y., 2016. Copper ecotoxicology of marine algae: a methodological appraisal. Chem. Ecol. 32, 786-800.

Levy, J.L., Stauber, J.L., Jolley, D.F., 2007. Sensitivity of marine microalgae to copper: The effect of biotic factors on copper adsorption and toxicity. Sci. Total. Environ. 387, 141-154.

Long, E.R., Macdonald, D.D., Smith, S.L., Calder, F.D., 1995. Incidence of adverse biological effects within ranges of chemical concentrations in marine and estuarine sediments. Environ. Manage. 19, 81-97.

Maldonado, M.T., Hughes, M.P., Rue, E.L., Wells, M.L., 2002. The effect of Fe and Cu on growth and domoic acid production by Pseudo-nitzschia multiseries and Pseudo-nitzschia australis. Limnol. Oceanogr. 47, 515-526.

Mallick, N., Mohn, F.H., 2003. Use of chlorophyll fluorescence in metal-stress research: A case study with the green microalga Scenedesmus. Ecotoxicol. Env. Saf. 55, 64-69.

Metaxas, A., Lewis, A.G., 1991. Copper tolerance of Skeletonema costa and Nitzschia thermalis. Aquat. Toxicol. 19, 265-280.

Miao, A.I.J.N., Wang, W.E.N.X., Juneau, Ph., 2005. Comparison of Cd , Cu , AND Zn toxic effects on four marine phytoplankton by pulse-amplitude-modulated fluorometry. Environ. Toxicol. Chem. 24(10), 2603-2611.

Milne, A., Landing, W., Bizimis, M., Morton, P., 2010. Determination of Mn, Fe, Co, Ni, Cu, Zn, 
$\mathrm{Cd}$ and $\mathrm{Pb}$ in seawater using high resolution magnetic sector inductively coupled mass spectrometry (HR-ICP-MS). Anal. Chim. Acta. 665, 200-207.

Mitrovic, S.M., Fernández Amandi, M., McKenzie, L., Furey, A., James, K.J., 2004. Effects of selenium, iron and cobalt addition to growth and yessotoxin production of the toxic marine dinoflagellate Protoceratium reticulatum in culture. J. Exp. Mar. Bio. Ecol. 313, 337-351.

Mooney, H.M., Patching, J.W., 1995. Triphenyltin inhibits photosynthesis and respiration in marine microalgae. J. Ind. Microbiol. 14, 265-270.

Naser, H.A., 2013. Assessment and management of heavy metal pollution in the marine environment of the Arabian Gulf: A review. Mar. Pollut. Bull. 72, 6-13.

Parkhurst, D.L., Appelo, C.A.J., 2013. Description of Input and Examples for PHREEQC Version 3 - A Computer Program for Speciation, Batch-Reaction, One-Dimensional Transport, and Inverse Geochemical Calculations. U.S. Geological Survey Techniques and Methods, book 6, chapter A43, 497 p. U.S. Geol. Surv. Tech. Methods, B. 6, chapter A43 6-43A.

Parsons, M.L., Aligizaki, K., Bottein, M.Y.D., Fraga, S., Morton, S.L., Penna, A., Rhodes, L., 2012. Gambierdiscus and Ostreopsis: Reassessment of the state of knowledge of their taxonomy, geography, ecophysiology, and toxicology. Harmful. Algae. 14, 107-129.

Peiffer, W.E., Ingle, R.T., Ferguson-miller, S., 1990. Structurally Unique Plant Cytochrome c Oxidase Isolated from Wheat Germ, a Rich Source of Plant Mitochondrial Enzymes. Biochemistry. 29(37), 8696-8701.

Perales-Vela, H.V., González-Moreno, S., Montes-Horcasitas, C., Cañizares-Villanueva, R.O., 2007. Growth, photosynthetic and respiratory responses to sub-lethal copper concentrations in Scenedesmus incrassatulus (Chlorophyceae). Chemosphere; 67, 2274-2281.

Pérez, P., Estévez-Blanco, P., Beiras, R., Fernández, E., 2006. Effect of copper on the photochemical efficiency, growth, and chlorophyll a biomass of natural phytoplankton assemblages. Environ. Toxicol. Chem. 25, 137-43.

Petersen, S., Gustavson, K., 2000. Direct toxic effects of TBT on natural enclosed phytoplankton at 
ambient TBT concentrations of coastal waters. Ecotoxicology. 9, 273-285.

Petersen, S., Gustavson, K., 1998. Toxic effects of tri-butyl-tin (TBT) on autotrophic pico-, nano-, and microplankton assessed by a size fractionated pollution-induced community tolerance (SFPICT) concept. Aquat. Toxicol. 40, 253-264.

Pezzolesi, L., Guerrini, F., Ciminiello, P., Dell'Aversano, C., Iacovo, E. Dello, Fattorusso, E., Forino, M., Tartaglione, L., Pistocchi, R., 2012. Influence of temperature and salinity on Ostreopsis cf. ovata growth and evaluation of toxin content through HR LC-MS and biological assays. Water. Res. 46, 82-92.

Pezzolesi, L.,Vanucci, S., Dell'Aversano, C., Dello Iacovo, E., Tartaglione, L., Pistocchi, R., 2016. Effects of $\mathrm{N}$ and $\mathrm{P}$ availability on carbon allocation in the toxic dinoflagellate Ostreopsis cf. ovata. Harmful. Algae. 55, 202-212.

Pistocchi, R., Mormile, a M., Guerrini, F., Isani, G., Boni, L., 2000. Increased production of extraand intracellular metal-ligands in phytoplankton exposed to copper and cadmium. J. Appl. Phycol. 12, 469-477.

Platt, T., Gallegos, C., Harrison, W., 1980. Photoinhibition of photosynthesis in natural assemblages of marine phytoplankton. J. Mar. Res. 38(4) 687-701

Pringault, O., Lafabrie, C., Avezac, M., Bancon-Montigny, C., Carre, C., Chalghaf, M., Delpoux, S., Duvivier, A., Elbaz-Poulichet, F., Gonzalez, C., Got, P., Leboulanger, C., Spinelli, S., Sakka Hlaili, A., Bouvy, M., 2016. Consequences of contaminant mixture on the dynamics and functional diversity of bacterioplankton in a southwestern Mediterranean coastal ecosystem. Chemosphere. 144, 1060-1073.

Protopopov, F.F., Matorin, D.N., Seifullina, N.K., Bratkovskaya, L.B., Zayadan, B.K., 2015. Effect of methylmercury on the light dependence fluorescence parameters in a green alga Chlamydomonas moewusii. Microbiol. Russian. Fed. 84, 822-827.

Ralph, P.J., Gademann, R., 2005. Rapid light curves: A powerful tool to assess photosynthetic activity. Aquat. Bot. 82, 222-237. 
Rodríguez-González, P., Encinar, J.R., Alonso, J.I.G., Sanz-Medel, A., 2006. Contamination of the Coastal Waters of Gijón (North West Spain) by Butyltin Compounds. Water. Air. Soil. Pollut. $174,127$.

Rue, E., Bruland, K., 2001. Domoic acid binds iron and copper: A possible role for the toxin produced by the marine diatom Pseudo-nitzschia. Mar. Chem. 76, 127-134.

Sabah, A., Bancon-montigny, C., Rodier, C., Marchand, P., Delpoux, S., Ijjaali, M., 2016. Chemosphere Occurrence and removal of butyltin compounds in a waste stabilisation pond of a domestic waste water treatment plant of a rural French town. Chemosphere. 144, 2497-2506.

Saifullah, S.M., 1978. Inhibitory effects of copper on marine dinoflagellates. Mar. Biol. 44, 299308.

Sakellari, A., Plavšić, M., Karavoltsos, S., Dassenakis, M., Scoullos, M., 2011. Assessment of copper, cadmium and zinc remobilization in Mediterranean marine coastal sediments. Estuar. Coast. Shelf. Sci. 91, 1-12.

Samson, G., Morissette, J.-C., Popovic, R., 1988. Copper Quenching of the Variable. Photochem. Photobiol. 48, 329-332.

Santore, R.C., Di Toro, D.M., Paquin, P.R., Allen, H.E., Meyer, J.S., 2001. Biotic ligand model of the acute toxicity of metals. 2. Application to acute copper toxicity in freshwater fish and Daphnia. Environ. Toxicol. Chem. 20, 2397-2402.

Schroder, W.P., Arellano, J.B., Bittnerll, T., 1994. Flash-induced Absorption Spectroscopy Studies of Copper Interaction with Photosystem I1 in Higher Plants. J. Biol. Chem. 269(52), 3286532870.

Schwarzenbach, R.P., Escher, B., Fenner, K., Hofstetter, T.B., Johnson, A.C., Gunten, U. von., Wehrli, B., 2006. The Challenge of Micropollutants. Science. 313(5790), 1072-1079.

Sellner, K.G., Doucette, G.J., Kirkpatrick, G.J., 2003. Harmful algal blooms: causes, impacts and detection. J. Ind. Microbiol. Biotechnol. 30, 383-406.

Sidharthan, M., Young, K.S., Woul, L.H., Soon, P.K., Shin, H.W., 2002. TBT toxicity on the 
marine microalga Nannochloropsis oculata. Mar. Pollut. Bull. 45, 177-180.

Simpson, S.L., Angel, B.M., Jolley, D.F., 2004. Metal equilibration in laboratory-contaminated (spiked) sediments used for the development of whole-sediment toxicity tests. Chemosphere. $54,597-609$.

Skrabal, S. a., Donat, J.R., Burdige, D.J., 1997. Fluxes of copper-complexing ligands from estuarine sediments. Limnol. Oceanogr. 42, 992-996.

Smith, P.J., 1996. Selective decline in imposex levels in the dogwhelk Lepsiella scobina following a ban on the use of TBT antifoulants in New Zealand. Mar. Pollut. Bull. 32, 362-365.

Solé, M., Morcillo, Y., Porte, C., 1998. Imposex in the commercial snail Bolinus brandaris in the northwestern Mediterranean. Environ. Pollut. 99, 241-246.

Stauber, J.L., Florence, T.M., 1987. Toxicity of copper complexes to the marine diatom Nitzschia closterium. Mar. Biol. 94, 511-519.

Strasser, R.J., Srivastava, A., Tsimilli-Michael, M., 2000. The fluorescence transient as a tool to characterize and screen photosynthetic samples. Probing Photosynth. Mech. Regul. Adapt. $443-480$.

Sunda, W.G., 1989. Trace metal interactions with marine phytoplankton. Biol. Oceanogr. 6, 411442.

Thomaidis, N.S., Stasinakis, A.S., Gatidou, G., Morabito, R., Massanisso, P., Lekkas, T.D., 2007. Occurrence of organotin compounds in the aquatic environment of Greece. Water. Air. Soil Pollut. 181, 201-210.

Tobin, J.M., Cooney, J.J., 1999. Action of Inorganic Tin and Organotins on a Hydrocarbon-Using Yeast, Candida maltosa. Arch. Environ. Contam. Toxicol. 36, 7-12.

Tornero, V., Hanke, G., 2016. Chemical contaminants entering the marine environment from seabased sources : A review with a focus on European seas. Mar. Pol. Bul. 112, 17-38.

Tseng, R.-K., Cooney, J.J., 1995. Action of tributyltin on enzymes of four bacteria. Environ. Toxicol. Chem. 14, 1113-1121. 
Van De Riet, J., Gibbs, R., Muggah, P., Rourke, W., Macneil, J., Quilliam, M., 2011. Liquid Chromatography Post-Column Oxidation (PCOX) Method for the Determination of Paralytic Shellfish Toxins in Mussels, Clams, Oysters, and Scallops: Collaborative Study. J. AOAC. Int. 94(4), 1154-1176.

Vasconcelos, M.T.D., Leal, M.F.C., 2001. Seasonal variability in the kinetics of $\mathrm{Cu}, \mathrm{Pb}, \mathrm{Cd}$ and $\mathrm{Hg}$ accumulation by macroalgae. Mar. Chem. 74, 65-85.

Vindimian, E., Robaut, C., Fillion, G., 1983. A method for cooperative or noncooperative binding studies using nonlinear regression analysis on a microcomputer. J. Appl. Biochem. 5, 261-8.

Waite, T.D., Morel, F.M.M., 1983. Characterization of complexing agents in natural waters by copper(II)/copper(I) amperometry. Anal. Chem. 55, 1268-1274.

Wake, H., 2005. Oil refineries: A review of their ecological impacts on the aquatic environment. Estuar. Coast. Shelf. Sci. 62, 131-140.

Walsh, G.E., McLaughlan, L.L., Lores, E.M., Louie, M.K., Deans, C.H., 1985. Effects of organotins on growth and survival of two marine diatoms, Skeletonema costatum and Thalassiosira pseudonana. Chemosphere. 14, 383-392.

White, J.S., Tobin, J.M., Cooney, J.J., 1999. Organotin compounds and their interactions with microorganisms. Can. J. Microbiol. 45, 541-554.

Wong, P.T.S., Chau, Y.K., Kramar, O., Bengert, G.A., 1982. Structure-toxicity relationship of tin compounds on algae. Can. J. Fish. Aquat. Sci. 39, 483-488.

Worms, I., Simon, D.F., Hassler, C.S., Wilkinson, K.J., 2006. Bioavailability of trace metals to aquatic microorganisms: importance of chemical, biological and physical processes on biouptake. Biochimie. 88(11), 1721-1731.

Yan, H., Pan, G., 2002. Toxicity and bioaccumulation of copper in three green microalgal species. Chemosphere 49, 471-476.

Yong, H.Y., Sidharthan, M., Shin, H.W., 2007. Effects of tributyl-tin on a marine microalga, Tetraselmis suecica. J. Environ. Biol. 28, 571-575. 
Yruela, I., Montoya, G., Picorel, R., Dei, E.E.A., 1992. Regular paper The inhibitory mechanism of $\mathrm{Cu}$ ( II ) on the Photosystem II electron transport from higher plants. Photosynth. Res. 227233.

Zohra, B.S., Habib, A., 2016. Assessment of heavy metal contamination levels and toxicity in sediments and fishes from the Mediterranean Sea ( southern coast of Sfax, Tunisia). Environ. Sci. Pollut. Res. Int. 23(14), 13954-13963. 


\section{FIGURES LEGEND}

Fig. 1: Measurements and computation of different contaminant concentrations at day 7 of the experiments. A) Relationship between measured and nominal concentrations of dissolved total $\mathrm{Cu}$ ( $\mathrm{r}=0.99$ and 0.99 for Alexandrium catenella and Ostreopsis cf. ovata, respectively). B) Relationship between measured dissolved total $\mathrm{Cu}$ and computed free bioavailable $\mathrm{Cu}^{2+}$ ions (the line represents the linear regression, $\mathrm{r}=0.95$ and 0.96 for A. catenella and $O$. cf. ovata respectively). C) Relationship between measured and nominal butyltin concentrations. The diagonal dashed lines indicate the 1:1 ratio for Figures 1A and 1C.

Fig. 2: Growth curves expressed in cell density (cells $\mathrm{mL}^{-1}$ ) on a logarithmic scale. A) Alexandrium catenella under $\mathrm{Cu}\left(\mathrm{Cu}^{2+}\right.$ in $\left.\mathrm{nM}\right)$ exposure. B) Ostreopsis cf. ovata under $\mathrm{Cu}\left(\mathrm{Cu}^{2+}\right.$ in $\left.\mathrm{nM}\right)$ exposure. C) A. catenella under BuT exposure (nominal concentrations in nM). D) O. cf. ovata under BuT exposure (nominal concentrations in $\mathrm{nM}$ ).

Fig. 3: Effect of contaminant exposure on growth rates $\left(\mu\right.$ in day $\left.{ }^{-1}\right)$. A) $\mathrm{Cu}\left(\mathrm{Cu}^{2+}\right.$ in $\left.\mathrm{nM}\right)$ and B) BuT (nominal concentration in $\mathrm{nM}$ ). Dashed colored lines represent Hill Modelization of the values to obtain the $\mathrm{EC}_{50}$ value, represented by the grey dashed lines.

Fig. 4: Pictures of the cells exposed to contaminants. A) Alexandrium catenella cells in good physiological state (up to $0.03 \mathrm{nM} \mathrm{Cu}^{2+}$ and $84.10^{-1} \mathrm{nM}$ of BuT). B-C) Round-shaped and altered $A$. catenella cells starting from $60.10^{-2} \mathrm{nM} \mathrm{Cu}^{2+}$. D-E) Lysed A. catenella cells from $27 \mathrm{nM}$ of BuT. F) Ostreopsis cf. ovata cells in good physiological state (up to $17.10^{-3} \mathrm{nM} \mathrm{Cu}^{2+}$ and $84.10^{-1} \mathrm{nM}$ of BuT). G-H) Round cells of $O$. cf. ovata from $0.03 \mathrm{nM}\left(\mathrm{Cu}^{2+}\right)$. I-J) Round-shaped and lysed cells of O. cf. ovata from $84 \cdot 10^{-1} \mathrm{nM}$ of BuT. Scale bar is $25 \mu \mathrm{m}$. 
Fig. 5: Effect of contaminants on maximum quantum yield of photosystem II (Fv/Fm expressed in $\%$ of control). A) Alexandrium catenella under $\mathrm{Cu}\left(\mathrm{Cu}^{2+}\right.$ in $\left.\mathrm{nM}\right)$ exposure. B) Ostreopsis cf. ovata under $\mathrm{Cu}\left(\mathrm{Cu}^{2+}\right.$ in $\left.\mathrm{nM}\right)$ exposure. C) A. catenella under BuT exposure (nominal concentrations in nM). D) O. cf. ovata under BuT exposure (nominal concentrations in nM).

Fig. 6: Effects of contaminant exposure on Ostreopsis cf. ovata photosynthetic parameters (Alpha, Ek and Pmax) extracted from PI curves. Figures A, B, C under $\mathrm{Cu}\left(\mathrm{Cu}^{2+}\right.$ in $\left.\mathrm{nM}\right)$ exposure and Figures D, E, F under BuT exposure (nominal concentrations in nM) using the Platt et al. (1980) equation.

Fig. 7: Contaminant exposure effects on toxin content. A-B) Toxin content of Ostreopsis cf. ovata ovatoxin a (ova-a) and ovatoxin b (ova-b); C-D) Toxin content of Alexandrium catenella, saxitoxins. The asterisk indicates a significant difference with control ( $\mathrm{p}<0.05$, one way ANOVA).

Fig. 8: Ranking of different $\mathrm{EC}_{50}$ values of phytoplankton groups and organisms exposed to $\mathrm{Cu}$ from the most tolerant to the most sensitive, expressed in $\mathrm{pCu}=-\log \left[\mathrm{EC} 50\right.$ of $\mathrm{Cu}^{2+}$ in $\left.\mathrm{nM}\right]$. 
A
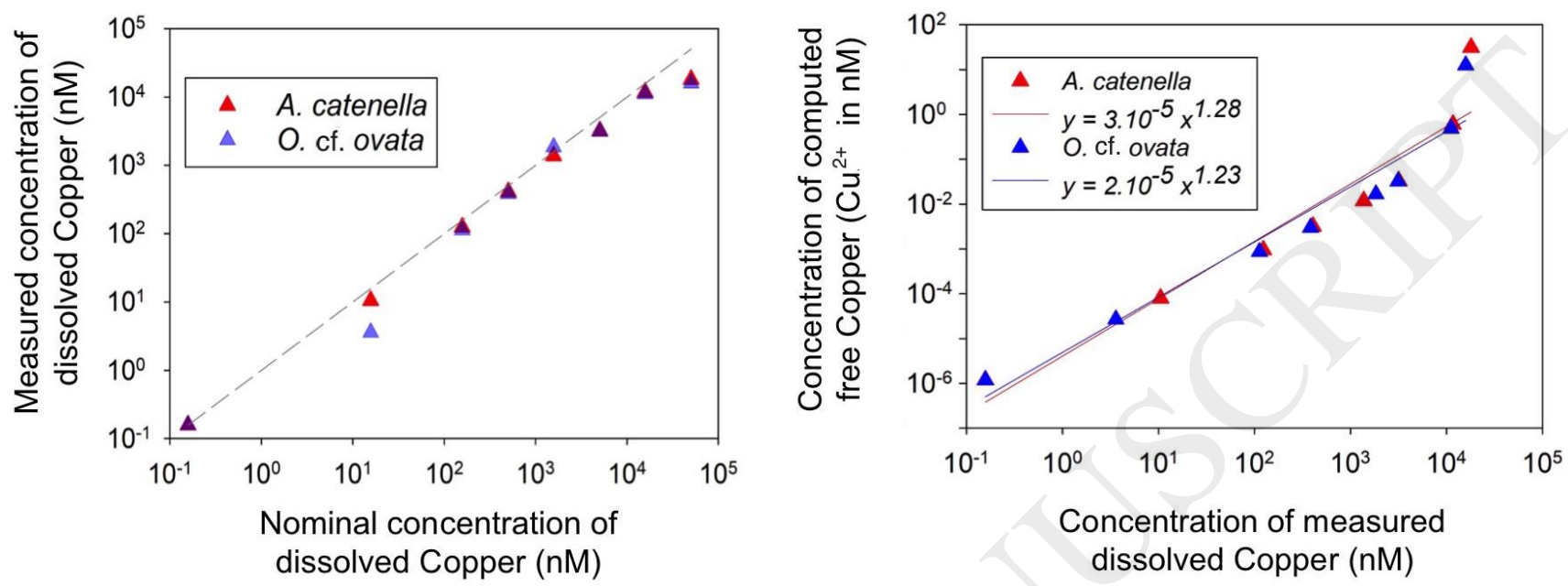

C

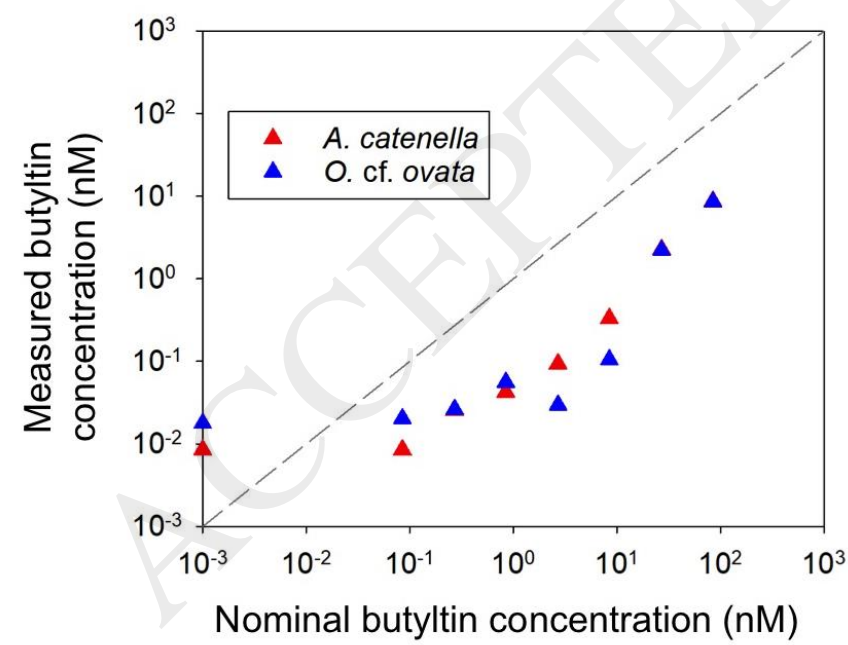

Figure 1 
Figure 2

A

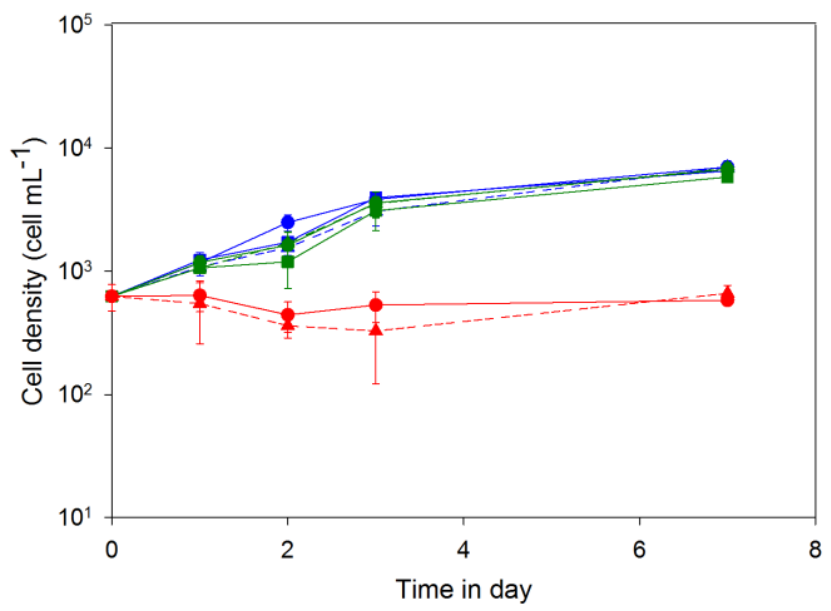

B

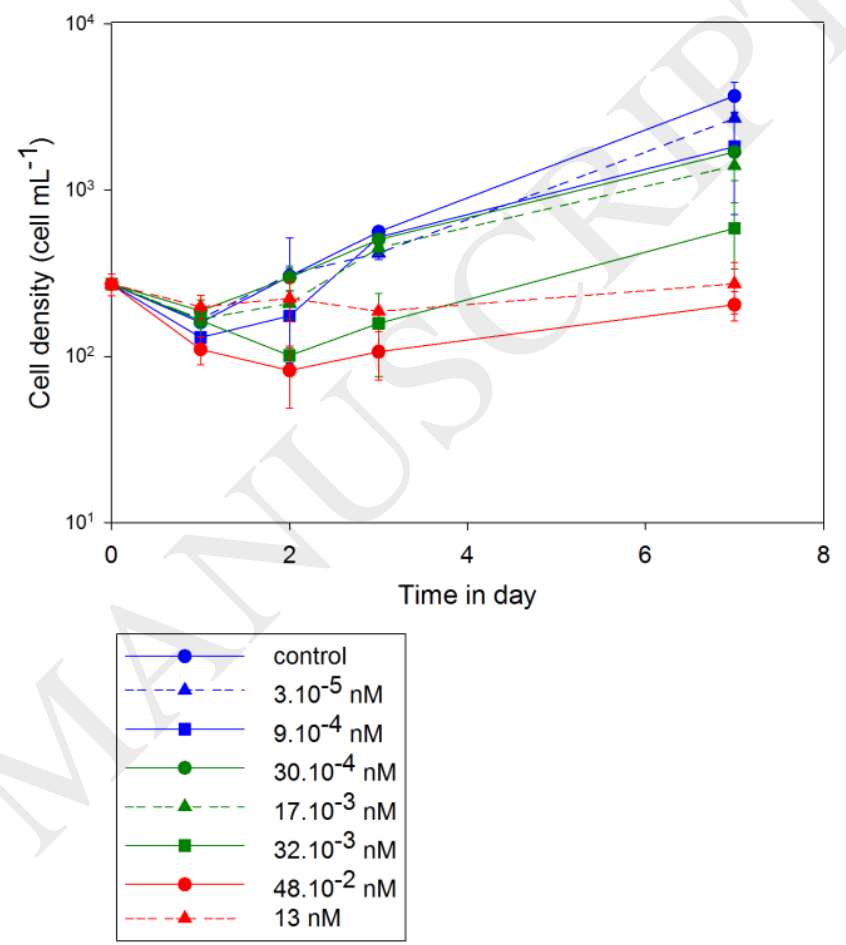


C

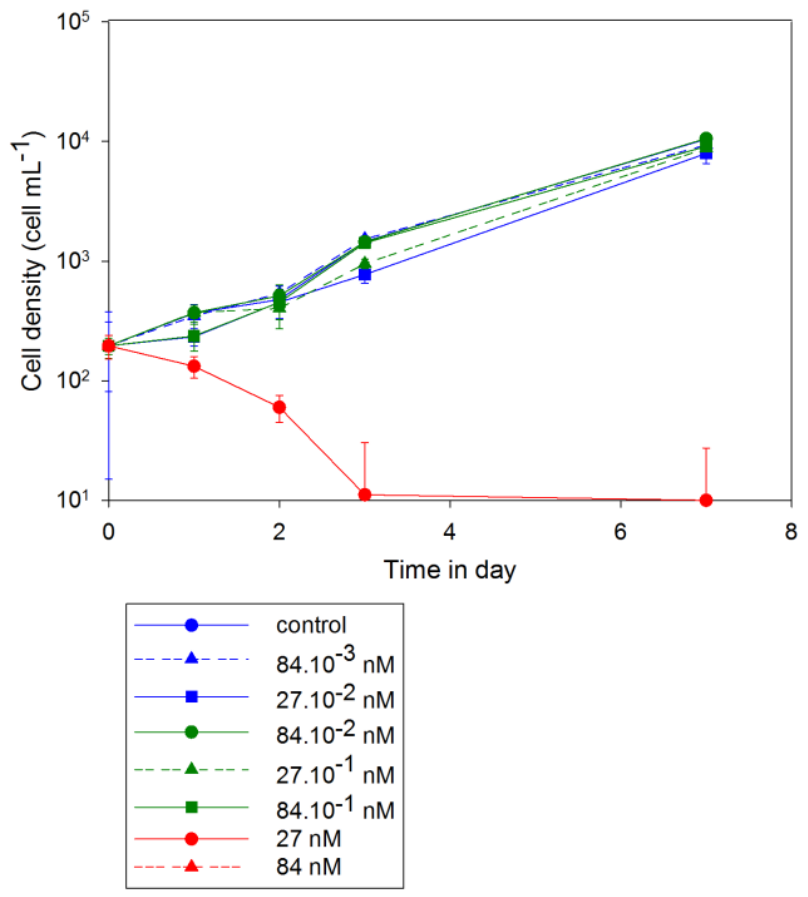

D

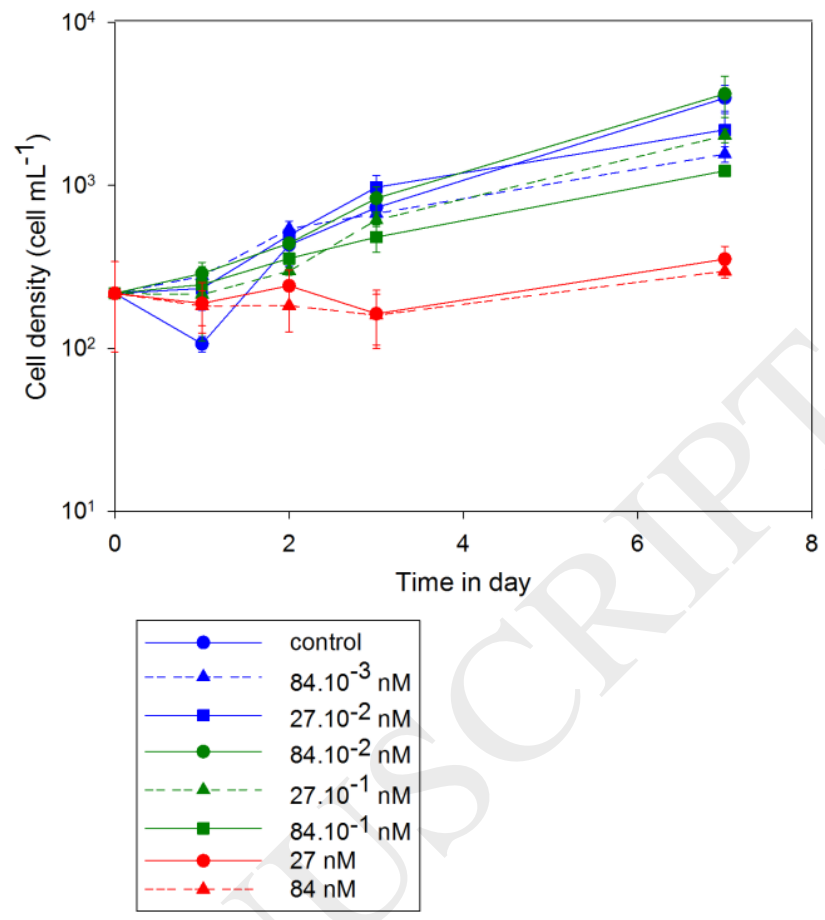

Figure 3

A

B 

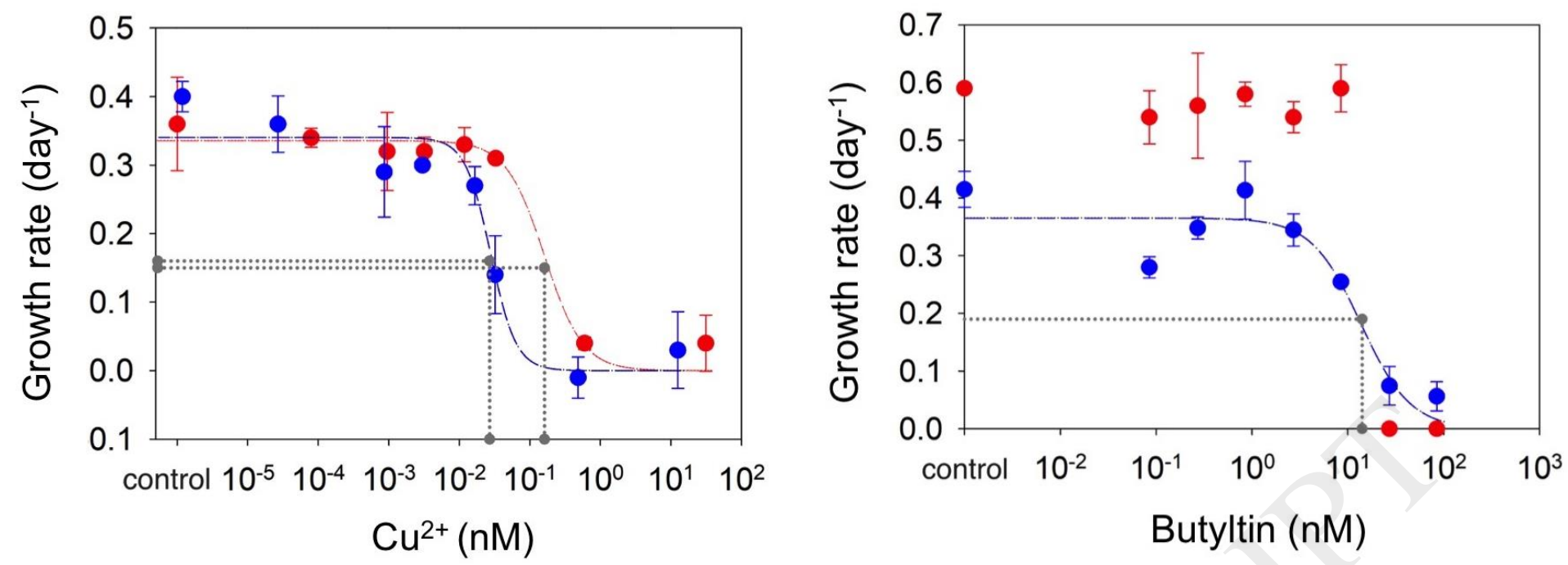

A. catenella

$E C_{50}=0.16( \pm 0.09) n M$

- O. cf. ovata

$E C_{50}=0.03( \pm 0.02) n M$

- A. catenella

$E C_{50}=N A$

- O. cf. ovata

$E C_{50}=14.2( \pm 6) n M$

Figure 4 


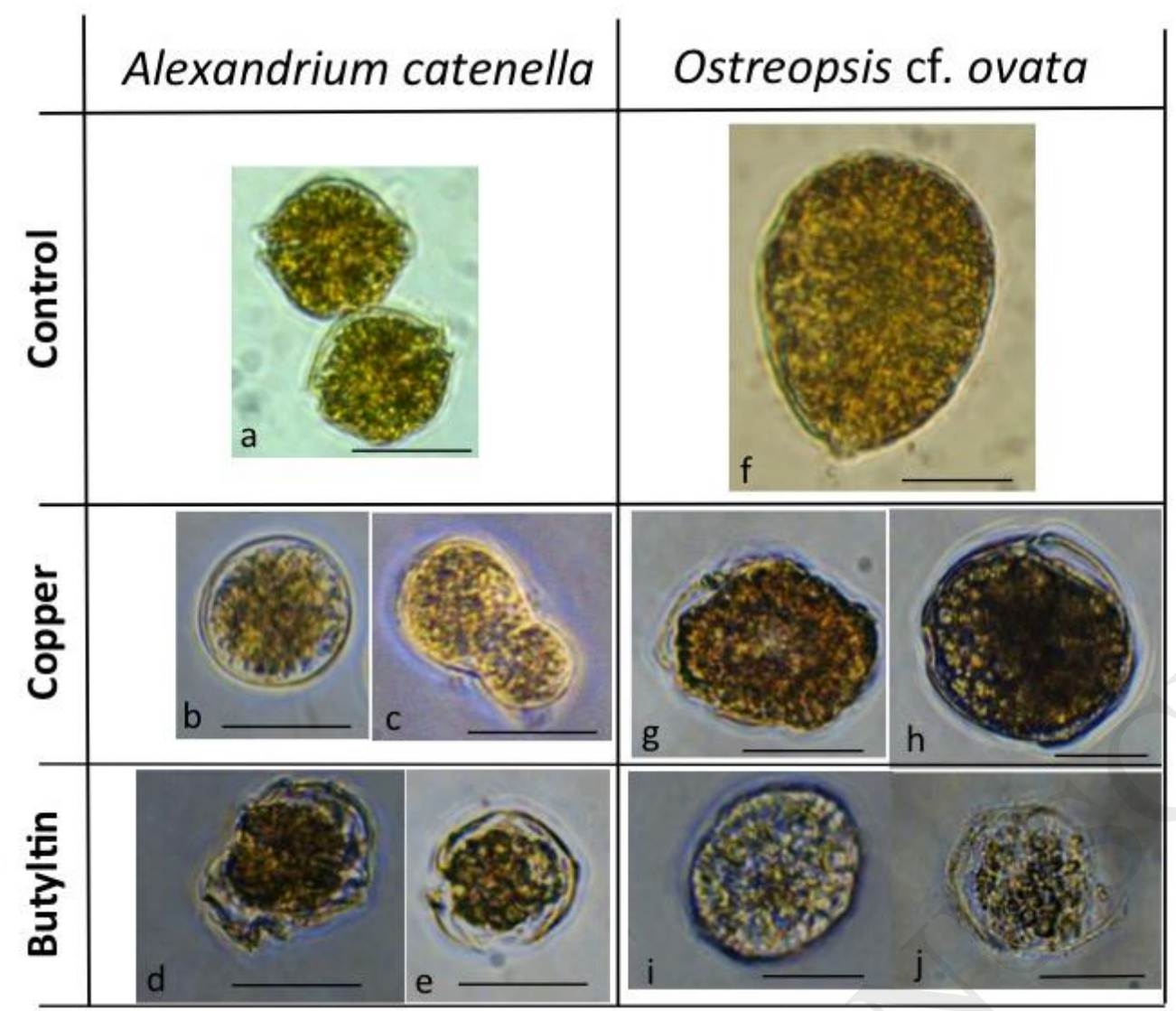


A

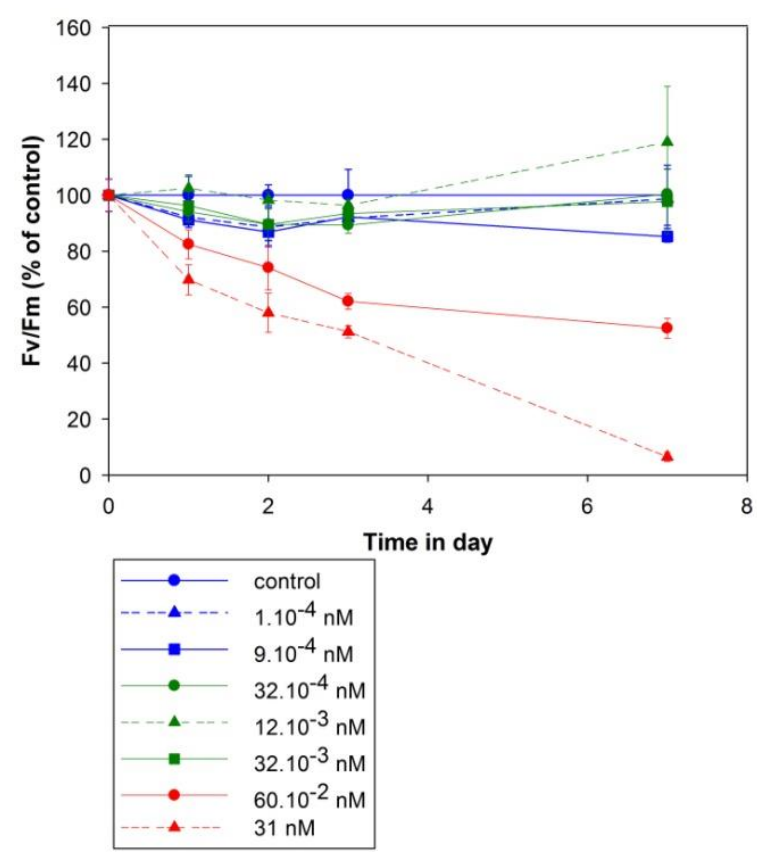

C

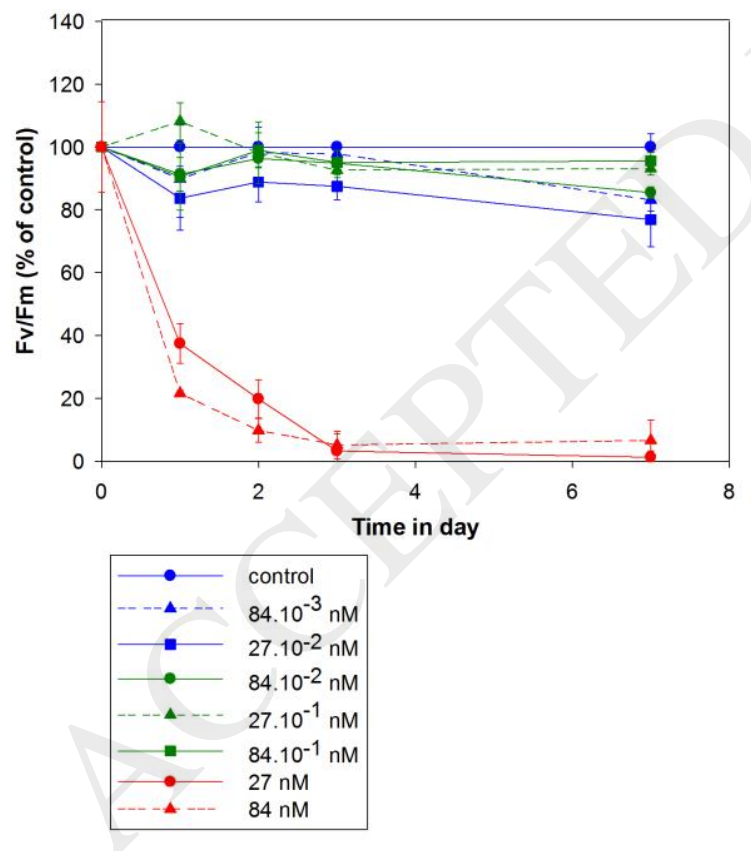

B

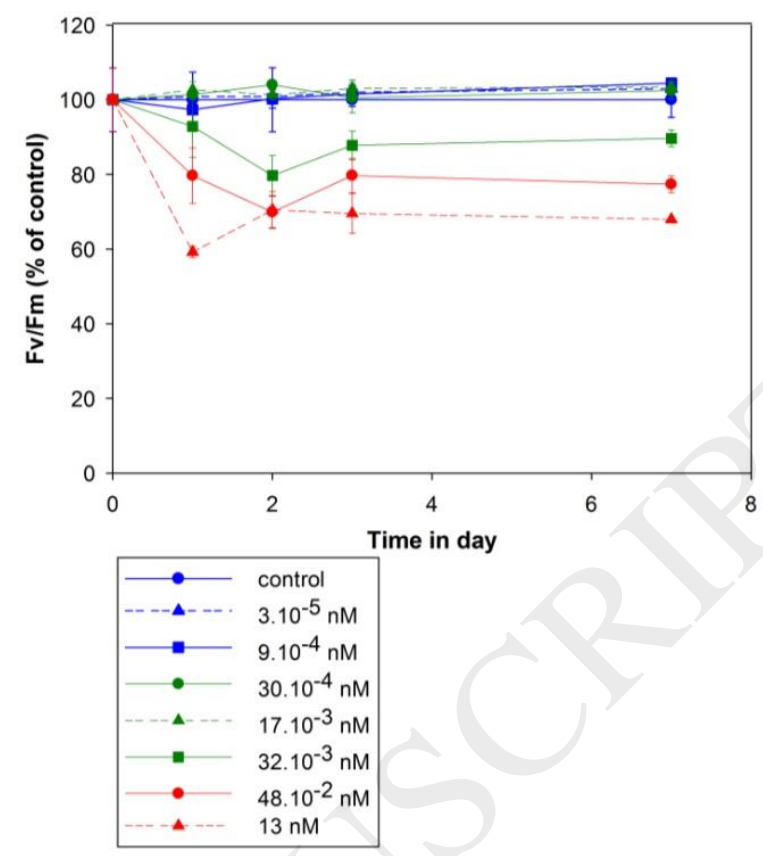

D

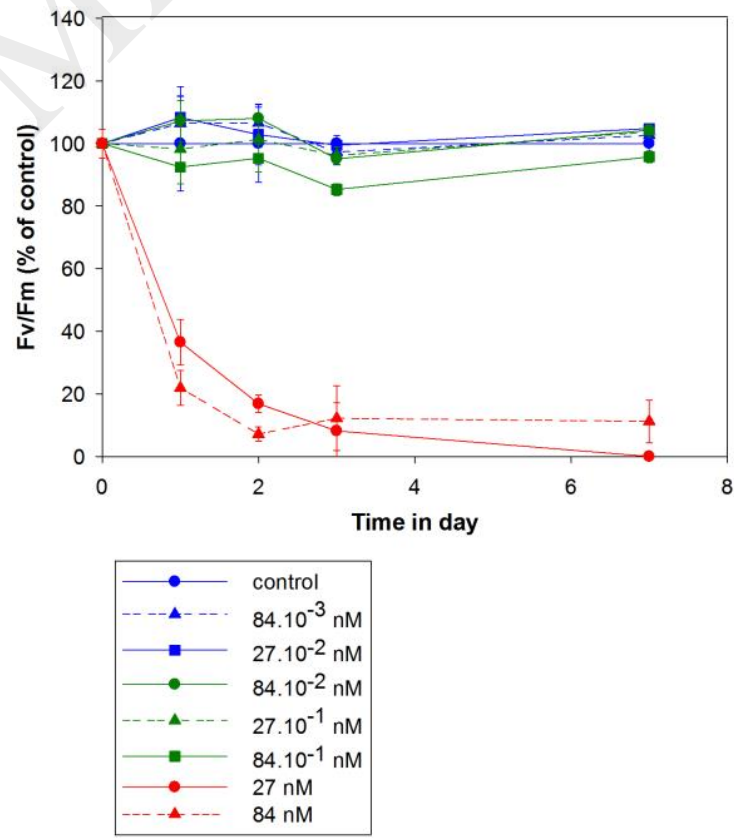

Figure 5 


\section{Figure 6}

A

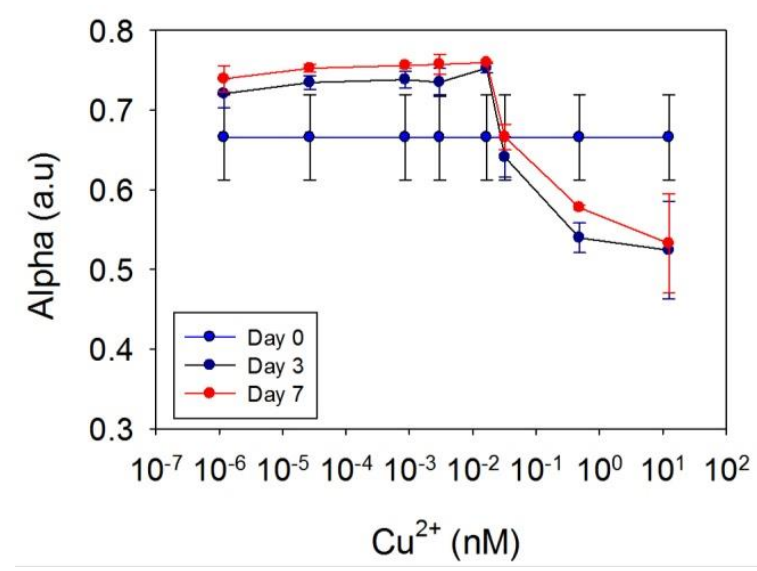

B

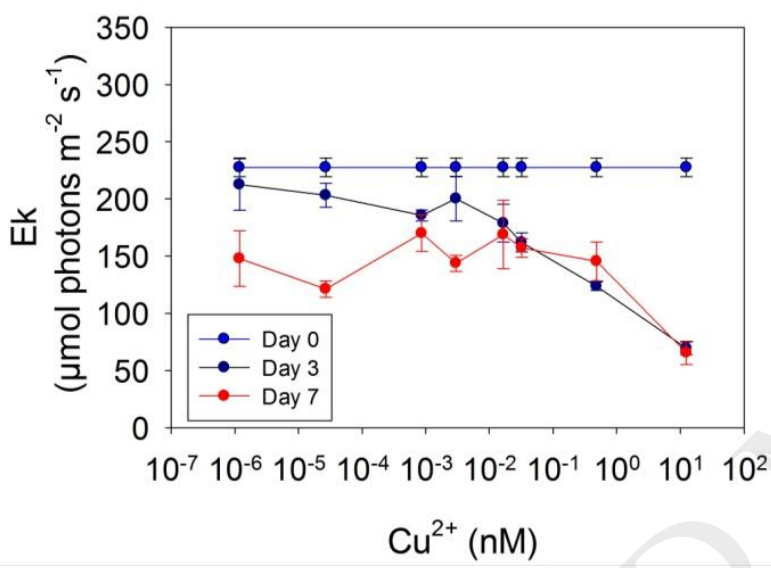

C

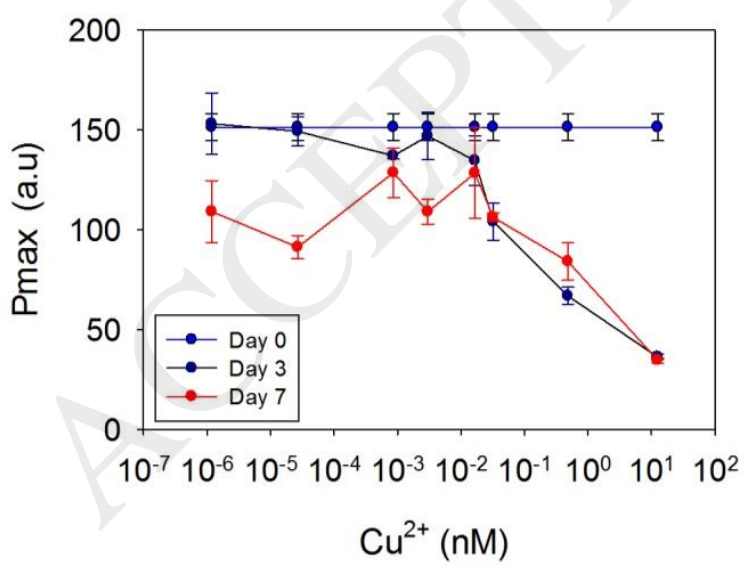

D

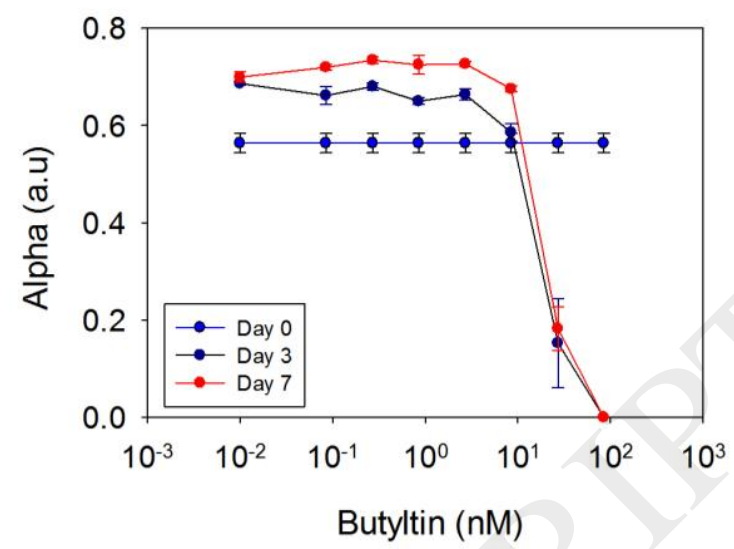

E

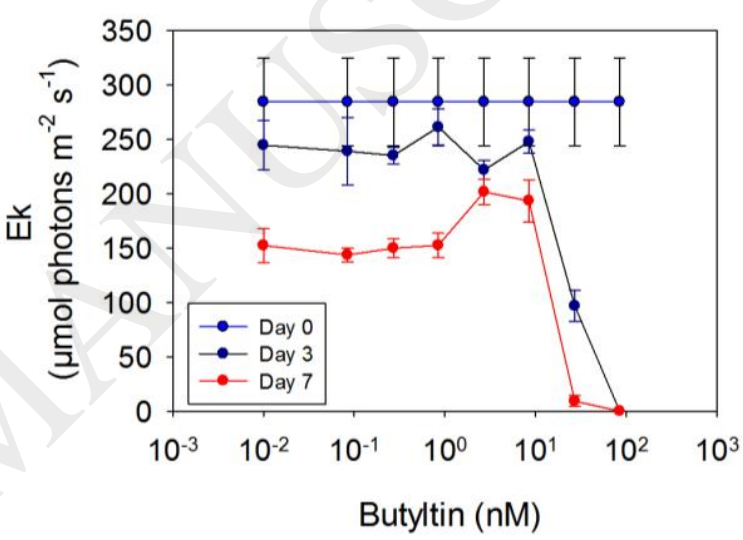

F

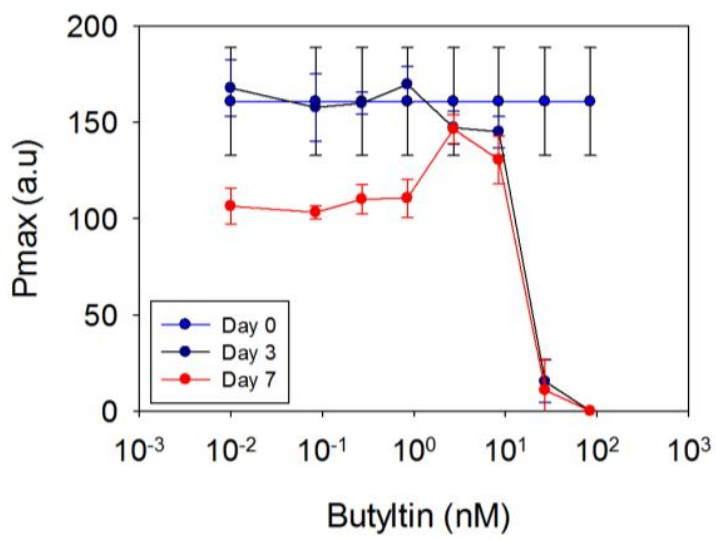


Figure 7

A

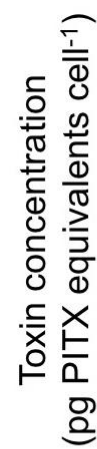

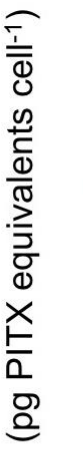

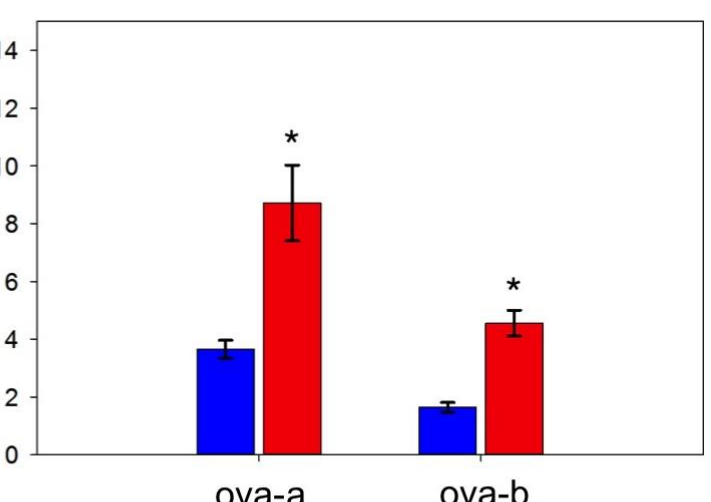

Control

$17.10^{-3} \mathrm{nM} \mathrm{Cu}^{2+}$

C

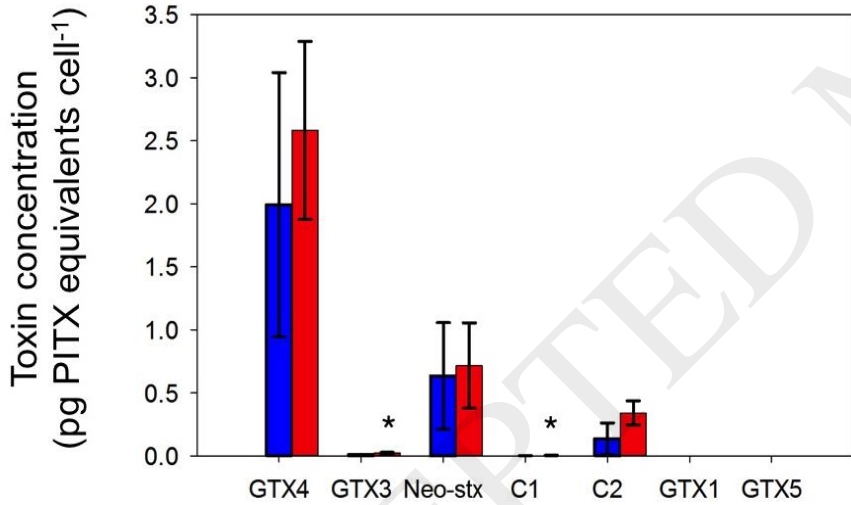

Control

$12.10^{-3} \mathrm{nM} \mathrm{Cu}^{2+}$
B

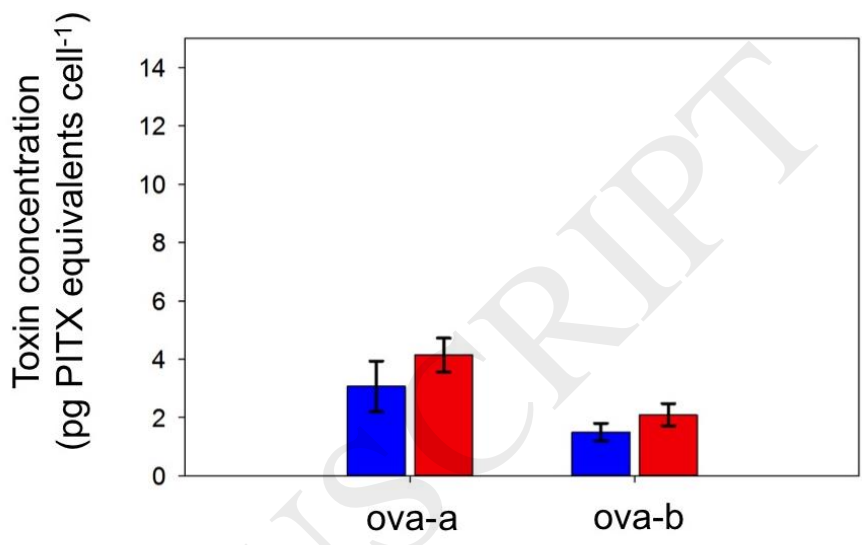

D

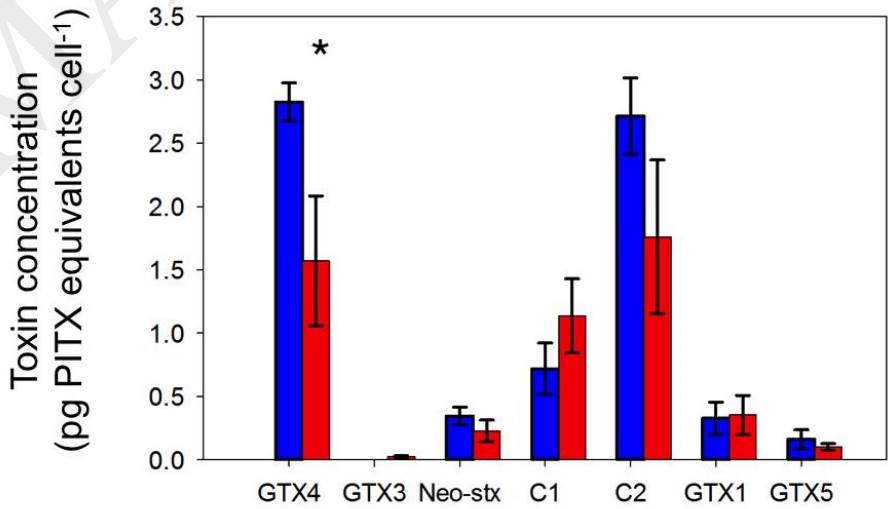

Control

2.7 nM Butyltin 


\section{Figure 8}

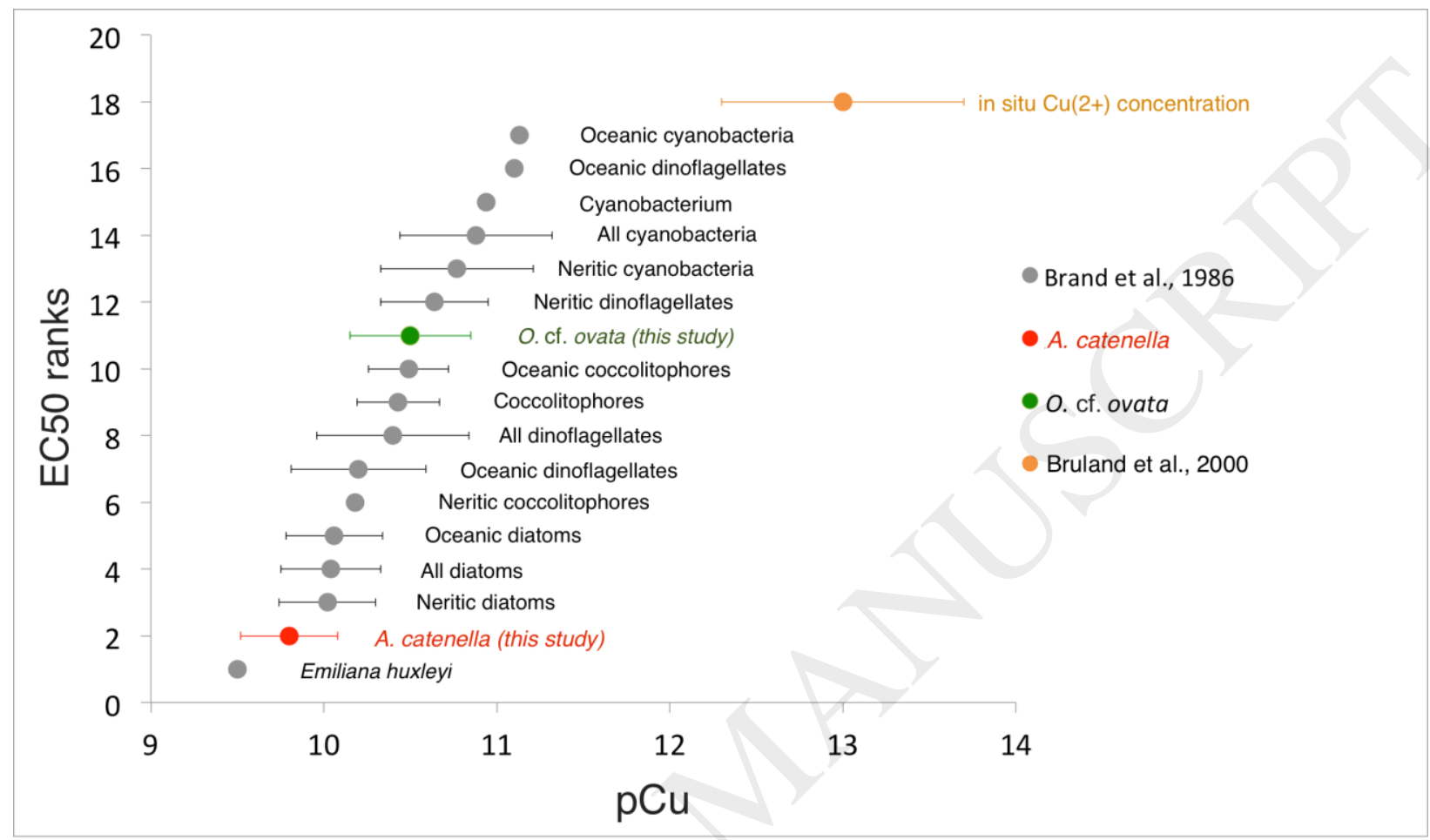


Table 1: Nominal, measured $[\mathrm{Cu}]$ and calculated dissolved bioavailable $\left[\mathrm{Cu}^{2+}\right]$ concentrations expressed in nM. Nominal and measured [butyltin] (Butyltin $=([\mathrm{MBT}]+[\mathrm{DBT}]+[\mathrm{TBT}])$ concentrations expressed in $\mathrm{nM} . \mathrm{T}_{0}$ and $\mathrm{T}_{7}$ correspond to the start and the end of the experiment, respectively.

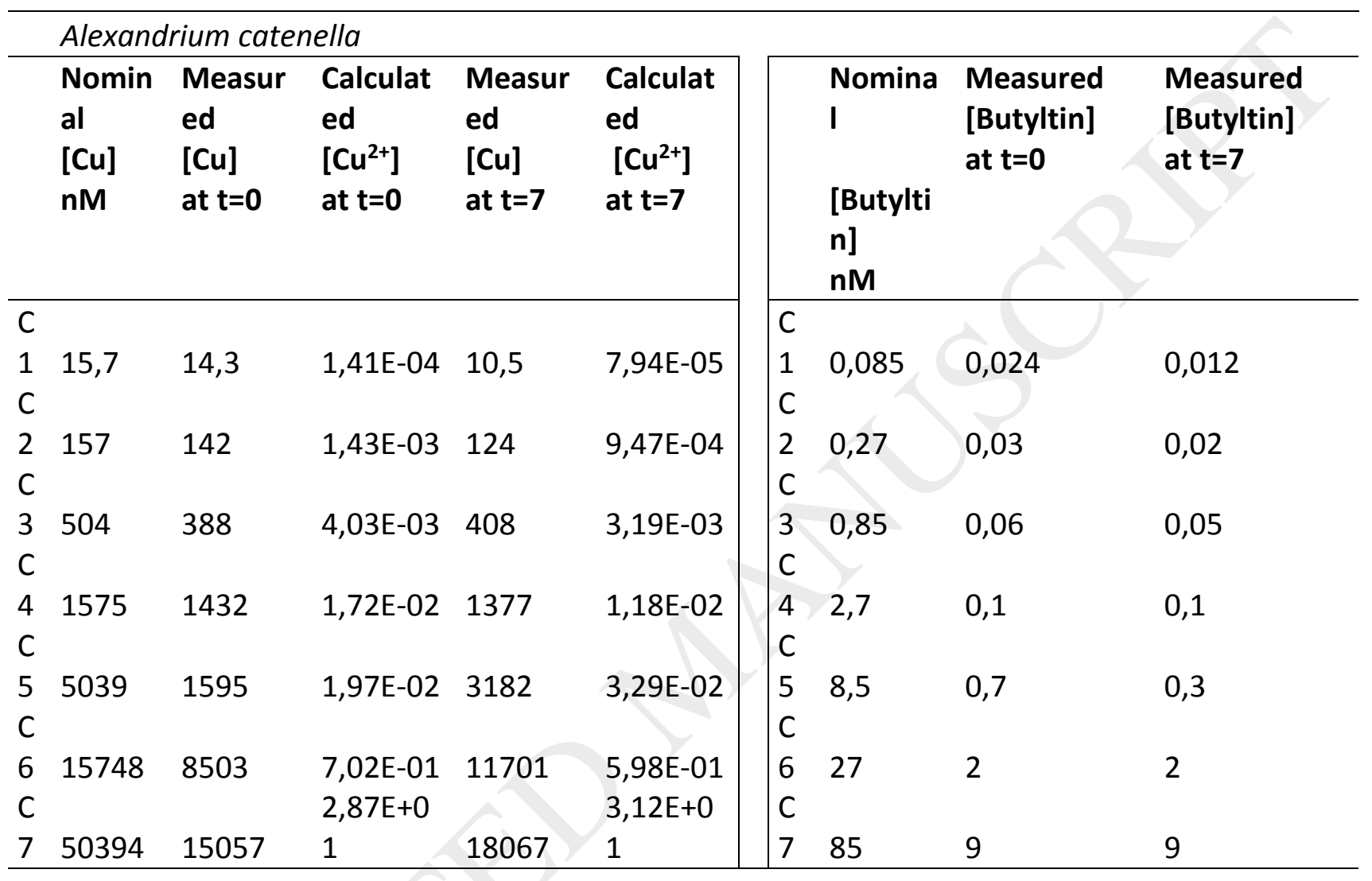

Ostreopsis cf. ovata

\begin{tabular}{|c|c|c|c|c|c|c|c|c|c|}
\hline & $\begin{array}{l}\text { Nomin } \\
\text { al } \\
{[\mathrm{Cu}]} \\
\mathrm{nM}\end{array}$ & $\begin{array}{l}\text { Measur } \\
\text { ed } \\
{[\mathrm{Cu}]} \\
\text { at } \mathrm{t}=0\end{array}$ & $\begin{array}{l}\text { Calculat } \\
\text { ed } \\
{\left[\mathrm{Cu}^{2+}\right]} \\
\text { at } \mathrm{t}=0\end{array}$ & $\begin{array}{l}\text { Measur } \\
\text { ed } \\
{[\mathrm{Cu}]} \\
\text { at } \mathrm{t}=7\end{array}$ & $\begin{array}{l}\text { Calculat } \\
\text { ed } \\
{\left[\mathrm{Cu}^{2+}\right]} \\
\text { at } \mathrm{t}=7\end{array}$ & & $\begin{array}{l}\text { Nomina } \\
\text { I } \\
\text { [Butylti } \\
\text { n] } \\
\text { nM }\end{array}$ & $\begin{array}{c}\text { Measured } \\
\text { [Butyltin] } \\
\text { at } t=0\end{array}$ & $\begin{array}{l}\text { Measured } \\
\text { [Butyltin] } \\
\text { at } \mathrm{t}=7\end{array}$ \\
\hline$C$ & & & & & & $C$ & & & \\
\hline 1 & 15,7 & 12,4 & $1,23 E-04$ & 3,6 & 2,69E-05 & 1 & 0,085 & 0,028 & 0,021 \\
\hline C & & & & & & $C$ & & & \\
\hline 2 & 157 & 136 & 1,37E-03 & 113 & $8,62 \mathrm{E}-04$ & 2 & 0,27 & 0,05 & 0,03 \\
\hline C & & & & & & C & & & \\
\hline 3 & 504 & 398 & 4,14E-03 & 385 & $3,01 E-03$ & 3 & 0,85 & 0,03 & 0,06 \\
\hline C & & & & & & $C$ & & & \\
\hline 4 & 1575 & 1518 & $1,85 \mathrm{E}-02$ & 1848 & $1,66 \mathrm{E}-02$ & 4 & 2,7 & 0,1 & 0,0 \\
\hline C & & & & & & C & & & \\
\hline 5 & 5039 & 1254 & $1,46 \mathrm{E}-02$ & 3143 & $3,23 E-02$ & 5 & 8,5 & 0,4 & 0,1 \\
\hline C & 15748 & 11264 & $3,32 E+0$ & 11168 & $4,84 \mathrm{E}-01$ & $C$ & 27 & 2 & 2 \\
\hline
\end{tabular}




\begin{tabular}{lllll|lllll}
6 & & 0 & & & & & \\
C & & $1,50 E+0$ & & $1,25 E+0$ & $\mid$ & & & \\
$C$ & & & \\
7 & 50394 & 20810 & 2 & 15902 & 1 & 7 & 85 & 6 & 6 \\
\hline
\end{tabular}

Table 1: Nominal, measured $[\mathrm{Cu}]$ and calculated dissolved bioavailable $\left[\mathrm{Cu}^{2+}\right]$ concentrations expressed in $\mathrm{nM}$. Nominal and measured [butyltin] (Butyltin $=([\mathrm{MBT}]+[\mathrm{DBT}]+[\mathrm{TBT}])$ concentrations expressed in $\mathrm{nM}$. $\mathrm{T}_{0}$ and $\mathrm{T}_{7}$ correspond to the start and the end of the experiment, respectively. 